\title{
GROWTH PERFORMANCE, CARCASS CHARACTERISTICS AND SOME HAEMATOLOGICAL CONSTITUENTS OF JAPANESE QUAILS FED DIETS CONTAINING DIFFERENT LEVELS OF SUNFLOWER AND SESAME MEAL AS A REPLACEMENT OF SOYBEAN MEAL \\ Abdel-Hakim, N. F.*; A. A. Amer*; A. F. Abdel-Azeem* ; Akila S. Hamza* and A. F. Fahrghly* \\ * Fac. Agric., Al-Azhar Univ., Naser City, Cairo, Egypt \\ ${ }^{\star *}$ Regional Center for Food and Feed
}

\begin{abstract}
This study was conducted to investigate the effect of replacing soybean meal (SBM) by locally available oilseed meals i.e., sunflower seed meal (SFM) and sesame seed meal (SSM) at different substitution levels 25, 50 and $100 \%$ on an isonitrogenous and isocaloric basis. A total number of 315 mixed sex $7^{\text {th }}$ days -old Japanese quails were randomly distributed into 7 treatment groups of 45 birds each, with three replicates containing 15 birds each. The experiment was carried out for 42 days (from 7 th to $48^{\text {th }}$ days of age). Treatment 1 was fed a control diet (100\% SBM), whereas treatment 2, 3,4,5,6 and 7 were fed diets containing 25, 50 and $100 \%$ of both SFM and SSM respectively. SBM was replaced with SFM and SSM on a weight basis. Experimental diets and fresh water were offered ad libitum along with the experimental period. Results revealed that substitution of SBM by SFM at $50 \%$ and $100 \%$ significantly $(p \leq 0.05)$ increased live body weight, body weight gain, protein and energy efficiency ratios compared with quails fed other dietary treatment groups. While feed intake, protein and energy intakes were significantly $(p \leq 0.05)$ higher for quails fed $100 \%$ SBM (control group) compared with quails fed SFM or SSM at different levels. However feed conversion ratio was the best for quails fed $100 \%$ and $50 \%$ SFM, followed by quails fed $100 \%$ SSM, 25\%SFM, 50\% SSM and control diet $(100 \%$ SBM) respectively, while the worst FCR was observed for quails fed $25 \%$ SSM. The highest mortality rate was observed for quails fed $100 \%$ SSM, while the lowest values were recorded for quails fed $25 \%$ SFM. Carcass traits expressed as percentage of body weight were significantly $(p \leq 0.05)$ affected by replacing SBM with SFM and SSM at different levels, where the percentage of total edible part were significantly ( $p \leq 0.05)$ higher for quails fed $50 \%$ SFM, while the lowest values were shown for quails fed $25 \%$ SSM and $100 \%$ SBM (control group). However total inedible parts percentage were significantly $(p \leq 0.05)$ higher for quails fed $100 \%$ SBM (control group), while the lowest values were recorded for quails fed $50 \%$ SFM. Concerning plasma parameters and carcass composition measured at the end of experimental period significant $(p \leq 0.05)$ differences were observed among the experimental groups due to feeding Japanese quails on diets containing different levels of SFM and SSM or control group, except with ALT values, where insignificant differences were detected. Replacement of SBM by SFM or SSM at 25, 50 and $100 \%$ levels reduced feed costs/birds. In general, conclusion based on the present results it could be recommended that SFM or SSM can safely replace SBM up to 50 and100\% without any adverse effects on growth performance or carcass traits of Japanese quail and using of SFM in quail diets as a plant protein alternative source was better than SSM. Keywords: (Japanese quail, sunflower meal, sesame meal, growth performance)
\end{abstract}




\section{INTRODUCTION}

In Egypt, there is a serious problem of feed shortage for livestock especially in poultry field. Also there is a continuous increase in the prices of the traditional feed ingredients, especially soybean meal, owing to its universal use. This obliged the nutritionists to search for alternative cheap and good untraditional feedstuffs, such as sunflower meal and sesame meal. However the scarcity of feed ingredients is the main obstacle to the development of the poultry industry in Egypt and in many developing countries. Recently the possible threats from pathogenic bacteria and greater variability in protein quality in animal protein sources encourage using the vegetable protein in poultry diets (Rama Rao et al. 2006). Plant protein sources i.e., sunflower seed meal (SFM)) and sesame seed meal (SSM) have the potential to be major feed ingredients for poultry in many countries not suitable for extensive soybean (SBM) cultivation. Sunflower (Helianthus annuus) is an oilseed cultivated worldwide for oil sources, due to its great capability of adaptation to different climatic and soil conditions (Ra-vindran and Blair, 1992). The by -product rendered by the oil industry, sunflower meal (SFM), is used as an alternative source of protein in livestock nutrition. It's crude protein (CP) content depends on dehulling and oil extraction process ranging from 29 to $45 \%$, having an inverse relation to crude fiber (CF) content, which ranging from 14 to $32 \%$ (FEDNA, 1994). Moreover the high fiber content and low lysine content limiting the use of SFM in poultry diets. On the other hand sesame (Sesamum indicum) meal (SSM) contains most of the essential amino acids at adequate amounts for the substitution of soybean meal (SBM) in practical diets, with the exception of lysine, for both growing broiler and laying hens (Scott et al., 1982). SSM is widely grown for caculinary use in Asian and African countries, which produce nearly 95\% (FAO, 2004) of world sesame seed. Rajesh et al (2006) reported that SFM can be safely included by replacing SBM up to 33 to $66 \%$ in broiler diets without and with enzyme mixture respectively to get a better performance. However Rama Roa et al. (2008) showed that the crude protein content of sunflower seed meal (SSM) was lower than that of SBM $(296$ and $448 \mathrm{~g} / \mathrm{Kg}$ ), but methionine, cystine, calcium, phosphorus and ether extract were higher (7.2 and 5.7, 6.8 and 6.5, 12.7 and $0.3,13.8$ and $5.7,57.7$ and $9.5 \mathrm{~g} / \mathrm{Kg}$, respectively). SSM contained lower concentration of lysine, threonine, isolucine, leucine and valine $(6.2,8.7,8.9,16.6$ and $11.4 \mathrm{~g} / \mathrm{Kg}$,) compared with those found in SBM $(26.7,17,20.4,36.4$ and $21.3 \mathrm{~g} / \mathrm{kg}$, respectively).The same authors added that body weight gain of broiler chickens was not affected by feeding on diets containing sunflower seed meal (SSM) up to 0.67 $\%$ proportion of SBM in starter and finisher diets $(360$ and $310 \mathrm{~g} / \mathrm{Kg}$ respectively). In other study by Abdel-Hakim et al. (2009) showed that replacing 50 or $100 \%$ of SBM protein by SFM, SSM and LSM revealed no significant effect on final body weight of broiler chickens. Also they indicated that carcass traits and mortality were not affected by replacing SBM protein by 50 or $100 \%$ of SFM and SSM. The present investigation was conducted with Japanese quails to study the effect of replacing SBM with graded levels 
of both SFM and SSM on growth performance, carcass traits, carcass composition, some hematological traits and economical efficiency of the experimental diets.

\section{MATERIALS AND METHODS}

This study was carried out at the Poultry Experimental Station, Faculty of Agriculture, Al-Azhar University, Naser City, Cairo, Egypt, in order to investigate the effect of replacing SBM with graded levels of both SFM and SSM at 25,50 and $100 \%$ on growth performance, carcass characteristics, carcass composition and some hematological traits of Japanese quails. Also economic efficiency was calculated at the end of growing period. Chicks were raised together during the fist $7^{\text {th }}$ days of age to avoid any mortalities occurred during the first life of age. At the end of the $7^{\text {th }}$ days of age all chicks were individually weighed at start of experiment to the nearest gram to avoid the differences in weight at start of experiment and the average weight ranged between (16.93 to $18.04 \pm 0.41 \mathrm{~g}$ ). A total number of 315 chicks at $7^{\text {th }}$ days old were used in this study. The chicks were randomly distributed into 7 treatment groups containing 45 birds each. Each treatment was represented by 3 replicates each with 15 birds. The chicks were weighed at weekly intervals during the experimental growing period, and average live body weight was recorded. Body weight gain, feed intake, feed conversion ratio ( $\mathrm{g}$ feed $/ \mathrm{g}$ gain), protein intake, energy intake, protein and energy efficiency ratios and mortality rate were recorded. SBM was replaced by SFM and SSM at levels of 25, 50 and $100 \%$ (weight /weight). Diets composition and proximate chemical analysis were done before the start of experiment according to AOAC (1994), and shown in Table (1). Samples of raw material of SFM and SSM were taken for chemical composition and some amino acid analysis and the values are given in Table (2). All diets were isocaloric and isonitrogenous and contained the nutrient requirements of growing Japanese quails according to $N R C$ (1994). Both diet and water were offered ad libitum along the experiment duration. At the end of experimental period ( $48^{\text {th }}$ days of age) samples of blood were taken from 10 birds ( 5 female and 5 males) for each treatment. Birds were fasted 24 hour prior to blood sampling. All samples were centrifuged at $3000 \mathrm{rpm}$ for 15 minutes. Plasma was separated and stored in vials at $-20 \quad C^{\circ}$ until analysis. All tests were analyzed by using Spectrophotometer apparatus (Model 722 GRATING). The constituents of blood were determined e.g., total plasma protein according to (Henry, 1964), albumin (Doumas and Biggs, 1972), lipid (Zollner and Kirsch, 1962), triglycerides (Dryer, 1970), cholesterol (Allain et al., 1971), HDL (Warnick et al., 1983), LDL (Assmann et al., 1984) AST and ALT (Reitman and Frankel, 1957). Commercial kits (made in Egypt) by Diamond Company, Stanpio, Laboratory Pasteur Lab. Diagnostic and biodiaquastic Company were used for the blood analysis. The globulin values obtained by subtracting the values of albumin from the corresponding values of total protein. Also albumin/globulin ( $\mathrm{A} / \mathrm{G}$ ratio) values were obtained by dividing the values of albumin on the values of globulins. 
Abdel-Hakim, N. F. et al.

Table (1): Composition and determined analysis of the Japanese growing diets based on maize and soybean meal, sunflower seed meal and sesame seed meal

\begin{tabular}{|c|c|c|c|c|c|c|c|}
\hline \multirow{3}{*}{ Ingredients } & \multirow{3}{*}{$\begin{array}{c}\text { Control } \\
(100 \% \text { SBM })\end{array}$} & \multicolumn{6}{|c|}{ Substitution levels (\%) } \\
\hline & & \multicolumn{3}{|c|}{ SSM } & \multicolumn{3}{|c|}{ SFM } \\
\hline & & 25.0 & 50.0 & 100.0 & 25.0 & 50.0 & 100.0 \\
\hline Ground yellow corn $(8.5 \%)$ & 55.00 & 56.50 & 53.70 & 49.40 & 55.00 & 53.0015. & 48.00 \\
\hline Soybean meal (44\%) & 30.00 & 22.50 & 15.00 & - & 22.50 & 00 & - \\
\hline Sesame seed meal (35\%) & - & 07.50 & 15.00 & 30.00 & - & - & - \\
\hline Sunflower seed meal (37.6\%) & - & - & - & - & 07.50 & 15.00 & 30.00 \\
\hline Fish herring meal (62\%) & 09.00 & 10.90 & 12.00 & 15.20 & 10.10 & 11.50 & 13.80 \\
\hline Wheat bran (15.7\%) & 04.00 & 00.50 & 00.90 & - & 02.30 & 01.90 & 01.80 \\
\hline Sunflower oil & 01.20 & 01.30 & 02.60 & 04.60 & 01.80 & 02.90 & 05.60 \\
\hline Sodium chloride ( $\mathrm{Na} \mathrm{cl}$ ) & 00.22 & 00.22 & 00.22 & 00.28 & 00.22 & 00.22 & 00.22 \\
\hline Pr-mix* & 00.58 & 00.50 & 00.48 & 00.28 & 00.50 & 00.40 & 00.38 \\
\hline L-Lysine & - & 00.08 & 00.10 & 0.30 & 00.08 & 00.08 & 00.20 \\
\hline Total $(\mathrm{Kg})$ & 100.0 & 100.0 & 100.0 & 100.0 & 100.0 & 100.0 & 100.0 \\
\hline \multicolumn{8}{|l|}{ Calculated diet composition } \\
\hline CP\% & 24.08 & 24.08 & 24.00 & 24.11 & 24.03 & 24.10 & 24.20 \\
\hline $\mathrm{ME} \mathrm{Kcal/kg}$ & 2905 & 2903 & 2905 & 2904 & 2902 & 2900 & 2904 \\
\hline CF\% & 03.77 & 04.14 & 04.38 & 05.93 & 04.12 & 04.55 & 05.39 \\
\hline $\mathrm{Ca} \%$ & 00.80 & 00.98 & 01.13 & 01.54 & 00.95 & 00.95 & 01.13 \\
\hline Available phosphorous, $\%$ & 00.42 & 00.54 & 00.59 & 00.71 & 00.51 & 00.58 & 00.69 \\
\hline EE\% & 02.86 & 03.80 & 03.78 & 06.38 & 02.85 & 02.83 & 02.69 \\
\hline Lysine\% & 01.30 & 01.36 & 01.30 & 01.32 & 01.32 & 01.35 & 01.37 \\
\hline Methionine \% & 00.50 & 00.50 & 00.54 & 00.63 & 00.46 & 00.50 & 00.56 \\
\hline Methionine+ systine $\%$ & 00.81 & 0.86 & 00.92 & 01.05 & 00.86 & 00.88 & 00.92 \\
\hline \multicolumn{8}{|l|}{ Chemical diet composition: } \\
\hline $\mathrm{CP} \%$ & 23.80 & 25.05 & 24.70 & 24.30 & 23.50 & 24.00 & 24.56 \\
\hline EE\% & 02.80 & 04.00 & 04.11 & 07.09 & 02.80 & 02.98 & 03.08 \\
\hline CF\% & 04.00 & 05.06 & 06.10 & 06.10 & 05.11 & 05.19 & 06.18 \\
\hline
\end{tabular}

${ }^{*}$ Each 3 kilogram of mineral and vitamin pre-mix contains: Vit. A 12000000IU;Vit.D3 2200000IU; Vit. E $10000 \mathrm{IU}$;VitK 2000 MG;Vit B1 1000 mg; VitB24000 mg; Vit B12 10mg;Vit B6 1500mg;Niacin 20000mg;Pantothenic acid 10000mg; Folic acid $1000 \mathrm{mg}$;Biotin 50 mg; Cholin chloride 50000 mg; Copper 10000mg;lodine 1000mg;Iron 3000mg;Zinc 5000mg;Manganmese5500; Mg and Selenium10mg.

Table (2): Chemical composition and some amino acid contents of SFM and SSM compared with SBM

\begin{tabular}{|c|c|c|c|}
\hline Items & SFM $^{*}$ & SSM $^{\text {** }}$ & SBM $^{\text {*** }}$ \\
\hline Moisture \% & 9.50 & 6.20 & $11.0^{1}$ \\
CP\% & 37.60 & 35.0 & 44.0 \\
EE\% & 0.71 & 12.70 & 0.80 \\
CF\% & 13.43 & 15.76 & 7.00 \\
Ca\% & 0.40 & 1.43 & 0.29 \\
Total phosphorous \% & 1.25 & 0.93 & 0.81 \\
Available phosphorous,\% & 0.42 & 0.31 & 0.27 \\
Gross energy K cal/kg & 4500 & 4900 & 3450 \\
Lysine \% & 1.35 & 1.06 & 2.69 \\
Methionine\% & 0.81 & 1.0 & 0.62 \\
Systine \% & 0.53 & 0.68 & 0.66 \\
\hline
\end{tabular}

* SFM=sunflower meal, ${ }^{\star \star}$ SSM=sesame meal, ${ }^{\star \star \star}$ SBM=soybean meal

1-According to analysis of NRC (1994)

2-Available phosphorous, \%.= calculated as a basis of digestible forms usually account for only $30-40 \%$ of the total phosphorus 
At the end of growing period in order to determine the carcass characteristics and carcass chemical composition, 6 quails from each treatment were randomly selected with equal numbers in terms of sex ( 3 females and 3 males), and a total of 42 quails were slaughtered for the $7^{\text {th }}$ treatments. Samples of carcass were also taken to carry over the routine chemical composition according to standard methods of the Association of Official Analytical Chemists (A.O.A.C., 1994). At the end of experiment, the economical efficiency of the product was calculated from the input and output analysis based upon the differences in both growth rate and feeding cost as described by Bayoumi (1980). Data were subjected to analysis of variance using two way classifications ( 3 sources $x 4$ levels) using the General linear model of (SPSS, 2005, version 14.0), INC., Chicago, For Windows. Significant differences among means were determined by Duncan's multiple range tests (Duncan's 1955) at 5.0\% level of significant. Arcsine of the square root of the some variable was used to convert all percentage values prior to analysis. All obtained data were analyzed by using the following Model:

where,

$$
X_{i j k}=M+\alpha_{i}+B_{j}+\left(\alpha_{i} \times B_{j}\right)+e_{i j k}
$$

$\mathrm{M}=$ General mean.

$\alpha_{i}=$ Effect of $A$ factor (Sources).

$B j=$ Effect of $B$ factor (Levels).

$\left(\boldsymbol{\alpha}_{\mathrm{i}} \times \boldsymbol{B}_{\mathrm{j}}\right)=$ Interaction between $\mathrm{A}$ and $\mathrm{B}$.

$\mathbf{e}_{\mathrm{ijk}}=$ Stander error for observations.

\section{RESULTS AND DISCUSSION}

\section{Chemical composition and some amino acid of SFM and SSM compared with SBM}

The data of chemical composition of SFM, SSM compared with SBM are illustrated in Table (2). Results revealed that SFM and SSM are rich in crude fiber, calcium, total phosphorus, gross energy and methionine content compared with SBM. However SSM contains higher levels and values of ether extract, crude fiber, calcium, gross energy, methionine, systine and gross energy compared with those present in SFM and SBM. On the other hand SBM contains higher level of CP percentage (44\%) than those found in SFM (37.6\%) and SSM (35\%), although both SFM and SSM have moderate level of CP\% compared to SBM. Generally, the chemical composition of both SFM and SSM may be considered as a preliminary indication to their feeding values as an alternative or new alternative ingredients plant protein sources in quail's diet, which can be used to resolving the shortage of SBM in Egypt. These results are partially in agreement with those obtained by Senkoylu et al. (1997) and Sayed (2002) who showed that SFM contains 33.2\% CP, 3\% EE, $24.97 \% \mathrm{CF}, 4.06 \%$ ash and $34.77 \%$ NFE. The variation in the chemical composition of SFM might be due to the varity of the seeds, the processing method and or the degree of dehulling or decortications (Ra-vindran and Blair, 1992). Also Sohair et al. (2001) indicated that SFM contains 10.83, 
$32.03,1.87,23.60$ and $9.25 \%$ for moisture, CP, EE, CF and ash respectively. Rama- Rao et al. (2006) indicated that SFM had higher concentration of calcium, phosphorous, methionine and cystine and lower energy content than SBM. In other study reported by Rama -Roa et al. (2008) showed that - crude protein content of SSM was lower than that of SBM (296 vs $448 \mathrm{~g} / \mathrm{Kg}$, respectively), but methionine, cystine, $\mathrm{Ca}, \mathrm{P}$ and ether extract were higher ( 7.2 vs $5.7,6.8$ vs $6.5,12.7$ vs $0.3,13.8$ vs $5.7,57.7$ vs $9.5 \mathrm{~g} / \mathrm{Kg}$, respectively). SSM contained lower concentration of lysine, threonine, isolucine, leucine and valine $(6.2,8.7,8.9,16.6$ and $11.4 \mathrm{~g} / \mathrm{Kg}$, respectively), compared to SBM $(26.7,17,20.4,36.4$ and $21.3 \mathrm{~g} / \mathrm{kg}$, respectively).

\section{Growth performance}

Results of growth performance of Japanese quails including live body weight, body weight gain, feed intake, feed conversion ratio, protein intake, energy intake, protein efficiency ratio, energy efficiency ratio and mortality rate as affected by feeding control and diets containing different levels of SFM and SSM are given in Table (3).

\section{Live Body weight (LBW) and body weight gain (BWG)}

Averages of LBW at start of experiment ( $7^{\text {th }}$ days of age) ranged between $16.93( \pm 0.40 \mathrm{~g})$ to $18.04( \pm 0.27 \mathrm{~g})$ with insignificant differences. While at the end of the experimental period ( $48^{\text {th }}$ days of age) the analysis of variance showed that quails fed $50 \%$ and $100 \%$ SFM exhibited significantly $(p \leq 0.05)$ heavier LBW, followed by quails fed $100 \%$ SSM, $25 \%$ SFM, $50 \%$ SSM, $100 \%$ SBM(control group), while quails fed $25 \%$ SSM recorded the lowest LBW. Regardless of levels quails fed SFM recorded the highest LBW compared with quails fed SBM or SSM respectively. The results of LBW as affected by dietary levels indicated that LBW was significantly $(p \leq 0.05)$ higher for quails fed diet containing $100 \%$, followed by those fed 50,25 and $100 \%$ (control group) respectively. Concerning BWG the same trend was observed, where the quails fed 50 and 100\% SFM recorded the highest $(p \leq 0.05)$ values compared with quails fed other dietary treatments. However BWG was higher for quails fed SFM, followed by quails fed SSM and SBM respectively. Regarding the effect of different levels the data indicated that LBW was higher for quail's fed $100 \%$, compared with other dietary treatment groups. It is interesting to note that replacing SBM by SFM at levels 50 or 100 $\%$ or SSM at $100 \%$ showed better LBW and BG compared with other substitution levels or $100 \%$ SBM (control group). The increase of LBW of quails fed SFM or SSM may be due to these ingredients having higher values of gross energy and SFM and SSM have higher levels of methionine compared with values present in SBM. These results are confirmed by Kazemi and Daghir (1971) who noticed that chicks fed diet containing SFM as plant protein source were significantly heavier in their weight than those fed diets containing SBM or cotton seed meal (CSM). Also Kazemi and Kratzer (1980) found that body weight gain of chicks fed SFM were significantly $(p \leq 0.05)$ higher than those fed the other protein sources. 
J. Animal and Poultry Prod., Mansoura Univ., Vol. 2 (6), June,2011

3 
Abdel-Salam et al (1985) reported that body weight of chicks fed on diets containing SSM was significantly lower than those of chicks fed SFM or diet containing SBM and corn gluten meal (CGM). Also Sayed (2002) illustrated that adding SFM at $10 \%$ to broiler diet recorded the best parameters of growth performance compared with broilers fed 5 and $15 \%$ SFM or those fed control group. On the other hand Rama- Rao et al (2006) found that replacement of SBM with SFM up to $67 \%$ in starter and $100 \%$ in finisher diet did not affect weight gain. Also Rama- Rao et al. (2008) found that body weight gain of broiler chickens was not affected, when fed diet containing of SSM up to 360 and $310 \mathrm{~g} / \mathrm{kg}$ respectively. Abdel-Hakim et al. (2009) reported that replacing 50 or $100 \%$ of SBM protein with SFM protein revealed no significant effect on final body weight of broiler chickens, while final body weight decreased significantly in broiler fed diets containing SSM at 50 or $100 \%$ levels.

\section{Feed intake (FI), protein intake (PI) and energy intake (EI)}

The analysis of variance indicated that feed intake, protein intake and energy intake were significantly $(p \leq 0.05)$ decreased as the levels of SFM and SSM in the diets of Japanese quails increased. The decreases of FI and consequently protein and energy intake due to the fact that SSM and SFM have higher content of crude fiber and high phytate content than that present in SBM (Hossain and Jauncy(1989), which are responsible for the decrease of FI. Concerning the effect of sources the results indicated that quails fed SBM showed higher FI, PI and El compared with those fed SFM and SSM respectively. The same trend was observed for the effect of graded levels, thus quails fed $100 \%$ (control) recorded the higher values of $\mathrm{FI}, \mathrm{PI}$ and $\mathrm{EI}$ compared with quails fed 25,50 and $100 \%$ respectively. These results are partially in agreement with those obtained by Mamputu and Buhr (1995) who showed that increasing of sunflower seed meal (SSM) levels in the diet of chickens from 30; 45 to $60 \%$ as replacement of SBM dietary crude protein resulted in depression of feed intake. Also Tiwari et al. (2005) found that the use of SFM and Niger cake (NC) in quail diets as a replacement of SBM at 50, 60 and $70 \%$ levels causes a reduction in feed intake. While Christaki et al. (1994) reported that daily feed intake of growing Japanese quail was not significantly affected by feeding diet containing $35 ; 50$ and $65 \mathrm{~g} / \mathrm{Kg}$ of SFM. Also Tyagi et al. (2003) illustrated that feed intake of broiler was not altered at any level of SFM (0;5 or $10 \%)$ during both starter and finisher period. Also Rama- Rao et al. (2006) observed that feed intake was significantly higher for broiler fed diets replaced with SFM up to 67 to $100 \%$ at 21 and 49 days of age. Abdel-Hakim et al (2009)) indicated that broiler chickens fed diet supplemented with SFM at $100 \%$ recorded higher feed intake as compared with birds fed control (SBM) or other dietary treatments fed SSM and linseed meal (LSM). Moreover El-Sherif et al. (1997) showed that replacing of SBM with 10,15 or $20 \%$ SFM had no significant effect on protein and energy intake of broiler chickens.

Feed conversion ratio (FCR), protein efficiency ratio (PER) and energy efficiency ratio (EER)

The results of FCR indicated that quails fed $100 \%$ and $50 \%$ SFM recorded the best FCR, while the worst values were observed for quails fed $25 \%$ SSM and $100 \%$ SBM(control group). Also quails fed SFM as dietary 
protein source showed the best FCR, followed by those fed SSM and SBM respectively. Regardless of sources quails fed diet containing $100 \%$ level recorded the best FCR compared with quails fed other dietary levels Concerning PER and EER results presented in Table (3) indicated that the higher $(p \leq 0.05)$ values of both traits were observed for quails fed $100 \%$ and $50 \%$ SFM, while the lowest values were recorded for quails fed $100 \%$ SBM and $25 \%$ SSM respectively. The effect of sources indicated that quails fed SFM exhibited higher PER and EER than those recorded for quails fed SBM or SSM. Regardless of sources the quails fed $100 \%$ recorded the higher values compared with quails fed other dietary levels. These results are in accordance with the results obtained by Mohan et al. (1990) who found that quail fed diet containing different sources of SSM and SFM gave better feed efficiency as compared with birds fed control diet. Moreover Mandlekar (1992) found that feed efficiency of birds was significantly improved, when fed diet containing high level of SFM. While Mamputu and Buhr (1995) found that feed conversion ratio was decreased for chicks fed SSM at 30,45 and $60 \%$ of SBM protein. Rajesh et al. (2006) reported that replacing SBM by SFM at 33 or $66 \%$ levels improved FCR of broiler chickens. While Rama-Rao et al. (2006) indicated that the replacement of SBM by SFM up to $67 \%$ in starter and $100 \%$ in finisher diets, depressed feed efficiency at 21 and 42 days of age respectively. Also Rama-Rao et al. (2008) indicated that feed efficiency was not affected by feeding broiler chickens on SSM up to 67\%proportion of SBM in starter and finisher diets $(360$ and $310 \mathrm{~g} / \mathrm{Kg}$. respectively). Abdel-Hakim et al.(2009) indicated that the best feed conversion ratio was recorded for broiler chickens fed the control diet(SBM), followed by broilers fed diet containing SFM at 50\% and $100 \%$ and SSM at $50 \%$ and $100 \%$. Concerning the effect of PER and EER El-Sherif et al. (1997) showed that replacing of SBM by 10, 15 or $20 \%$ SFM no significant effect on PER and EER of broiler chickens.

\section{Mortality rate}

Results of mortality rate occurred during the experimental period are given in the same Table. The analysis of variance indicated that the highest $(p \leq 0.05)$ mortality rate was observed for quails fed $100 \%$ SSM (T4), followed by quails fed $25 \%$ SSM, $50 \%$ SSM, 50\%SFM, 100\% SFM and $100 \%$ SBM (control group) respectively, while the lowest mortality rate was recorded for quails fed $25 \%$ SFM. Regarding the effect of sources, quails fed SSM showed the higher mortality than those recorded for quails fed SFM and SBM. The effect of levels on mortality rate quails fed $100 \%$ showed the highest values, followed by those fed 50, 25 and 100\%(control) respectively. These results are in agreement with those for Arafa et al. (2001) who reported that chicks fed diets containing SSM recorded higher mortality rate compared with chicks fed SBM. While Tekeba et al. (2007) observed that mortality rate of broiler chickens was not significantly affected, when fed diet containing $17.3 \%$ of SSM. Abdel-Hakim et al. (2009) showed that no effect of incorporation of plant protein sources i.e., SFM, SSM and LSM on mortality rate, when added in the diet of broiler chickens at 50 and $100 \%$ levels. 


\section{Chemical carcass composition}

Results of chemical carcass composition as affected by dietary treatments are given in Table (4). It would appear that all carcass composition parameters are significantly $(p \leq 0.05)$ affected by the dietary treatments or by sources and levels. The moisture content was significantly $(p \leq 0.05)$ higher in bodies of quails fed $100 \%$ SFM compared with quails fed other dietary treatments, while the lowest values were observed for quails fed $50 \%$ SSM. However the moisture content as affected by dietary sources showed its higher content in bodies of quails fed SBM and SFM compared with those fed on SSM. Regardless of sources quails fed $100 \%$ (control) recorded higher values, followed by those fed on 100, 25 and $50 \%$ respectively. Concerning crude protein contents the obtained data indicated that quails fed diet containing $25 \%$ SFM recorded significantly $(p \leq 0.05)$ higher values, followed by those fed 50\%SFM, $100 \%$ SSM, 100\%SFM, 100\% SBM, 50\% SSM and 25\% SSM respectively. The effect of sources on CP contents indicated that quails fed SFM have higher CP \% in their meat compared with those fed SBM or SSM. Regardless of sources CP\% was highest for quails fed $100 \%$ (control), followed by those fed $100 \%, 50 \%$ and $25 \%$ respectively. The results of EE\% indicated that the highest $(p \leq 0.05)$ levels were shown for quails fed $25 \%$ SSM, while the lowest level was observed for quails fed $100 \%$ SFM. The data of EE\% as affected by source indicated that quails fed SSM have higher EE\% in their meat compared with those fed SFM or SBM. The EE\% recorded for the levels regardless of sources indicated that significantly $(p \leq 0.05)$ higher values were recorded for quails fed $25 \%$ compared with quails fed other dietary levels. With respect of ash percentage the data indicated that quails fed $100 \%$ SFM recorded higher levels compared with quails fed the other dietary treatments, while the lowest values were recorded for quails fed $100 \%$ SSM. Regardless of levels ash percentage was higher for quails fed SFM, followed by those fed SBM and SSM respectively. The effect of levels indicated that quails fed $100 \%$ level recorded the highest value, followed by those fed 50,25 and $100 \%$ (control). Regarding to NFE\% the analysis of variance indicated that meat of quails fed $50 \%$ and $100 \%$ SFM contained higher values than those recorded for quails fed other dietary treatments. Also quails fed SFM as a source had higher level than quails fed SBM or SM. The effect of levels indicated that quails fed on $50 \%$ showed the highest values compared with other dietary levels. Concerning the effect of sex on chemical carcass composition the data indicated that there were insignificant differences were observed for all carcass chemical composition, except with moisture contents, where females had higher levels than males (Table 4). These results are partially in agreement with those obtained by Abdel-Hakim et al. (2009) who showed that all carcass chemical composition of broiler chickens at $7^{\text {th }}$ weeks of age were significantly $(p \leq 0.05)$ affected by feeding diets containing SFM, SSM and LSM at 50 and $100 \%$ levels. Where CP, ash and NFE\% were higher for chickens fed LSM at $100 \%$ as compared with those fed SFM and SSM at $100 \%$ level. While DM and EE \% decreased for chickens fed LSM at level $100 \%$, when compared with broiler fed SFM $100 \%$ and SSM $100 \%$. 
J. Animal and Poultry Prod., Mansoura Univ., Vol. 2 (6), June,2011 4 
While Ibrahim and El-zubeir (1989) recorded that carcass moisture and ash content of broiler chickens were significantly decreased, when levels of SFM increased in the diet, while protein and ether extract were not affected. Also Christaki et al. (1994) found that moisture and protein content in the carcass were not affected by feeding quail on diet containing 35; 50 and $65 \%$ of SFM, while significant differences were observed in fat and ash content. Further more El-Sherif et al. (1995) indicated that carcass compositions of broiler chickens was not affected, when fed diet supplemented with $75 \%$ extracted SFM as a replacement of SBM. Also El-Sherif et al. (1997) showed that replacing of SBM by 10,15 or $20 \%$ of SFM was no significant effect on meat composition of broiler chickens.

\section{Carcass characteristics}

Results of carcass characteristics as percentage of final body weight are presented in Table (5). The obtained data revealed that the applied treatments, sources and levels released significant $(p \leq 0.05)$ effect on liver, gizzard, heart, edible parts, dressing, total edible parts and total inedible parts percentage. Whereas the results of edible parts recorded significant $(p \leq 0.05)$ higher values for quails fed $50 \% \mathrm{SSM}$, followed in a significant decreasing order by quails fed $25 \%$ SFM, $50 \%$ SFM, $100 \%$ SBM , 100 SFM,25\%SSM and $100 \%$ SSM respectively. Regardless of levels quails fed SFM and SBM showed higher values compared with quails fed SSM. The effect of levels indicated that quails fed $50 \%$ recorded higher $(p \leq 0.05)$ values compared with quails fed other dietary levels. The results of dressing percentage indicated that quails fed $50 \%$ and $100 \%$ SFM exhibited the highest values, while the lowest values were recorded for quails fed 100\% SBM (control group). Regarding the effect of sources on dressing percentage the results indicated that quails fed SFM have higher values than those recorded for quails fed SSM and SBM respectively. Regardless of sources quails fed $100 \%$ level recorded the highest values, followed by quails fed 25, 50 and $100 \%$ (control) respectively. The values of total edible parts indicated that quails fed diet containing $50 \%$ SFM showed the highest $(p \leq 0.05)$ value, followed by quails fed $25 \%$ SFM, $100 \%$ SFM, $100 \%$ SSM, 50\%SSM, 25\%SSM and $100 \%$ SBM (control) respectively. Concerning the effect of sources on total edible parts, the results indicated that quails fed SFM recorded the best values, followed by quails fed SSM and SBM. The values of total edible parts as affected by dietary levels showed that quails fed $100 \%$ have higher values compared with quails fed other dietary levels. With respect of total inedible parts the analysis of variance showed that quails fed $100 \%$ SBM (control group) showed the highest values compared with quails fed other dietary treatments, while the lowest value was recorded for quails fed $50 \%$ SFM. Quails fed SBM as a dietary sources recorded higher values compared with those fed SFM or SBM. Also quails fed $100 \%$ (control) showed the higher total inedible parts, followed by quails fed 25, 50 and $100 \%$ (Table 5). From these results it is clear that SFM could replace SBM without any adverse effect on carcass traits of growing Japanese quails. These results are in accordance with the results reported by Rama - Rao et al. (2006) who found that the relative weights of gizzard and intestine increased with increasing levels of SFM in diet from $31.79 \%, 33,67 \%$ to $100 \%$ levels . 
J. Animal and Poultry Prod., Mansoura Univ., Vol. 2 (6), June,2011 5 
They concluded that SFM can replace up to two thirds of SBM corresponding to containing of 345 and $296 \mathrm{~g}$ SFM per $\mathrm{Kg}$ for starter and finisher phases, respectively without adverse effect on carcass characteristics. Also AbdelHakim et al. (2009) found that SFM or SSM could replace SBM at levels 50 or $100 \%$ without any hazardous effects on total edible parts of broiler chickens. While Tyagi et al. (2003) found that carcass organs, except neck did not differ among groups of broiler chickens fed diet containing SFM at levels of 0; 5 and 10\%. Also Rama-Roa et al. (2008) indicated that relative weights of giblet, liver and abdominal fat of broiler were not affected by including SSM up to $67 \%$ in replacement of SBM in starter and finisher broiler diets (360 and 310 $\mathrm{g} / \mathrm{Kg}$. respectively).

\section{Blood plasma constituents}

Table (6) shows the effect of replacement SBM by different levels of SFM and SSM on the blood plasma constituents of Japanese quails at the end of experimental period.

\section{Total plasma protein, albumin, globulin and $A / G$ ratio}

The analysis of variance indicate that quails fed 50 and $100 \%$ SFM recorded significantly $(p \leq 0.05)$ higher values of total plasma protein, albumin and globulin compared with quails fed other experimental diets, while the control group recoded the lowest $(p \leq 0.05)$ values. The values of $A / G$ ratio indicated that quails fed $25 \%$ and $100 \%$ SSM showed the highest values, followed by quails fed $50 \%$ SSM, $100 \%$ SBM (control), $25 \%$ SFM, $50 \%$ SFM and $100 \%$ SFM respectively. Concerning the effect of sources the results indicate that quails fed SFM exhibited the highest values of total protein, albumin and globulin, followed by those fed SSM and SBM respectively. The highest A/G ratio was observed for quails fed SSM than quails fed SBM or SFM. Regarding the effect of levels the obtained data indicated that quails fed diet containing $100 \%$ recorded the highest values of total protein and albumin than those observed for quails fed other dietary levels. Results of the same Table show that total globulin was higher for quails fed 100,50 and $25 \%$ levels than quails fed $100 \%$ (control). Insignificant differences were observed for $A / G$ ratio due to dietary levels. No effect of sex on total protein, albumin and globulin contents in blood plasma. While $A / G$ ratio was higher for males compared with females. These results agree with those obtained by. Rama-Rao et al. (2006) indicated that serum protein concentration progressively decreased with increasing SFM level in broiler diets from 33,67 to $100 \%$. The concentration of total protein was lowest for chicks fed diet containing $100 \%$ SFM than other levels. Diarra and Usman (2008) showed that serum protein, albumin and globulin were not affected in blood of chickens, when fed diet containing SSM at $12.5 \%$ level. However Abdel-Hakim et al. (2009) reported that there were significant differences were observed for blood plasma parameters measured at $7^{\text {th }}$ weeks of age due to adding of SFM, SSM and LSM in broiler diet at levels 50 and $100 \%$.Where the total protein and globulin were higher for chickens fed $100 \%$ SFM, $100 \%$ SSM and $50 \%$ LSM

Total plasma lipids, triglycerides, cholesterol, high density lipoprotein (HDL) and low density lipoprotein (LDL)

The results of total plasma lipids, triglycerides, cholesterol and HDL indicated that quails fed 100\% SBM (control group) recorded the highest 
$(p \leq 0.05)$ values compared with quails fed diet containing different levels of SFM and SSM. While the reverse trend were observed for LDL, where quails fed $100 \%$ SBM (control diet) showed the lowest values compared with quails fed diets containing SFM and SSM at 25, 50 and $100 \%$ levels respectively (Table 6). Concerning the effect of sources the data indicated that quails fed SBM recorded higher values of lipids, triglycerides, cholesterol, HDL compared with quails fed SSM or SFM. While LDL was higher for quails fed SSM and SFM compared with quails fed SBM diet. Regardless of sources quails fed 100 $\%$ ( control) recorded the highest $(p \leq 0.05)$ values compared with quails fed other dietary levels. Values of LDL were higher for quails fed diet containing 25,50 and $100 \%$ than values recorded for quails fed $100 \%$ (control). The decrease of cholesterol in blood of quails fed high levels of SFM may be due to fact that SFM has higher fiber content, which acting to decreases lipid in blood and increases execration of lipids in the faeces (Rama- Rao et al., 2004). Concerning the effect of sex on these parameters the statistical evaluation indicates that males showed significantly higher values for these traits compared with their females. Rama -Rao et al. (2004) observed that serum cholesterol concentration decreased in chickens, when fed diet containing different levels of SFM. Also Shrivastav and Johri (2005) found that serum cholesterol concentration decreased with the increase of sunflower oil meal in diets of laying quail from $7.5,15$, and 22.5 to $30 \%$ by weight of SBM. Furthermore Rama -Rao et al. (2006) found that cholesterol and triglycerides concentration decreased progressively in the blood of broiler chickens with increasing SFM in diets up to $67 \%$ in starter and $100 \%$ in finisher diets.

Aspartate transaminase (AST) and Alanine transaminase (ALT)

The data of AST and ALT values are also given in Table (6). The obtained data indicated that quails fed control diet (100\% SBM) recorded significantly $(p \leq 0.05)$ higher values of AST compared with quails fed other dietary experimental groups. The results indicate that quails fed SBM as a source showed the highest AST values, followed by quails fed SSM and SFM. Regardless of sources quails fed $100 \%$ (control) recorded the highest values compared with quails fed other dietary levels. Insignificant differences were recorded for ALT due to interaction or due to sources and levels. Concerning the effect of sex on both parameters results indicated that males has higher values of AST than females, while adverse trends were detected for ALT, where the females has higher values of ALT than those recoded for males.

\section{Economical efficiency}

Results of the economical efficiency of the experimental diets are presented in Table (7). The data indicated that quails fed 50 and 100\% SFM recorded lower feed cost and higher economical efficiency compared with quails fed other experimental diets or control diet. However the lowest economical efficiency was recorded by diet containing 25\% SSM as well as the diet containing SBM. Valdivie et al. (1982) indicated that the cost of feed required producing 1 ton of chickens live weight was lower, when fed diet containing sunflower oil meal compared with birds fed on control diet. 
Abdel-Hakim, N. F. et al.

6 
J. Animal and Poultry Prod., Mansoura Univ., Vol. 2 (6), June,2011

7 
El-Deek et al. (1999) found that the use of SFM in chickens and pullet diets to replace SBM decreases feed costs and improved net revenue. Sayed (2002) showed that broiler chickens fed diet containing SFM and LSM as plant protein sources at 5,10 and $15 \%$ levels recorded higher economical efficiency as compared with birds fed the control diet. Rajesh et al. (2006) reported that replacing SBM by SFM at 33 or $66 \%$ levels improved economic traits of broiler chickens. While Mandal et al. (2006) reported that the containing of sunflower seed meal (SSM) in maize- sorghum based diets did not alter the feed cost for gain and production statistically but were numerically lower in all the diets of broiler chickens.

In general conclusion based on the former results it could be recommended that SFM or SSM can be safely included by replacing SBM up to 50 and $100 \%$ without any adverse effects on growth performance or carcass traits of Japanese quail but using SFM in quail diets as a plant protein alternative source was better than of SSM.

\section{REFERENCES}

Abdel-Hakim, N.F.; A.A.Amer; T.M.Yonis and M.A.Assad (2009). Effect of partial complete replacement of soybean meal protein by some cheaper meals on performance and nutrients utilization of broiler chickens. Egypt.J.of Appl.Sci.,24(7)13-14.

Abdel-Salam,F.E;A.A. Aboul- Seoud and M.A.HRadwan (1985). Effect of liver meal as an animal protein source on feeding growing chicks.Annals of Agric.Sci.,Moshtohor,23:265.

Allain, C.C.; L.S. Poon; C.S.G. Ghan; G. Richmond and P.C.Fu (1971). Enzymatic colorimetric test. Choles. PAP Method. Clin.Chem.,20:47475.

Arafa, S; A.G. Abdallah and K.O.Abdel-Latif(2001). Influence of all-vegetable protein versus animal protein diets on performance ,carcass characteristics and immune response of broiler chicks reared under hot climatic. Egy.J Nut. And Feed (4):991-1003

Assmann, G.; H. U. Jabs; U. Kohnert; W. Nolte and H.S Chriewer (1984). LDL-cholesterol, polyvinyl sulphate Method (PVS). Clinc. Chem.Acta., 140,77-83.

Association of Official Analytical Chemists (A.O.A. C. 1994). Methods of analysis $\left(8^{\text {th }}-\right.$ ed) Washington 4, D.C. New York, 7:175

Bayoumi,S.B.(1980). Effect of different rations on egg production for breeding hens.M.Sc. Thesis ,Fac.Agric.Kafr-Elsheik, Tanta Univ.

Christaki,E.V.; P.P.Florou; G.A.L.Gouis and A.B.Spais (1994). Effect of sunflower seeds meal on the performance and carcass characteristics of growing Japanese quail. Animal Feed Sci. and Tech.,48 (2/1):174169.

Diarra,S.S. and B.A.Usman(2008): Performance of laying hen fed graded levels of soaked sesame (sesame indicum) seed meal as a source of methionine. International J. of Poultry Sci,7(4);323-327. 
Doumas,B.T. and H.G. Biggs (1972). In standard Methods of Clinical Chemistry. Quantitative colorimetric determination of albumin in serum or plasma. Academic Press, New York,7:175

Dryer,R.L.(1970). In Fundamentals of Clinical Chemistry. NW Teitz, Ed. WB Saunders, Philadelphia, p329.

Duncan's, D. B. (1955). Multiple ranges and multiple F-test. Biometrics, 11: 142.

El-Deek,A.A.; M.A.Abaza; M.Osman;Y.A.Attia; A.M.Khalaf (1999). Containing of sunflower meal and commercial enzyme to egg type strain ration during growth period 1-Effcets on growth performance ,mortality rate, blood parameters and economic returns. Egypt. Poultry. Sci., J.19(3): 529-547.

El-Sherif,K.; T.Gippert and D.Gerenndai (1995): Effects of different levels of expeller sunflower seeds meal in broiler diets. Allatt. es.Takar.44 (5): 427-435.

El-Sherif,K. K.; D.Gerendai and T.Gippert (1997). Complete substitution of sunflower meal for soybean meal with or without enzyme supplementation in broiler rations.Archiv-fur-Geflugelkunde,61(1):8-14.

FAO (2004). Oil seed production, FAO Yearbook/Annuaire Production/Annuario Production, Vol.58, p122 (Food and Agriculture Organization of united Nation).

FEDNA (1994). Norms de la Fundacion Esparola para el Desarrollo de la Valor nutritivo de lod concentrado de proteina vegetal.P.Garcia, C.de Blas, and G.G. Mateos. Unversidead politecnica de Madrid, Spain.(C.F. Rodriguez et al.2001).

Henry,R.J.(1964).Clinical Chemistry, Harper and Row Publishers. New York p.181.

Hossain,M.A. and K.Jauncy (1989). Studies on the protein ,energy and amino acid digestability of fish meal, mustard oil cake, linseed and sesame meal for common carp(Cyprinus carpio L.)Aquaculture 83:59-72.

Ibrahim,N.A. and E.A. Elzubeir (1989). Effect of feeding sunflower seed meal on skin colour and carcass chemical composition of broiler chicks. Sudan J. of Animal Production 2(1):35-39.

Kazemi,R. and F.H.Kratzer (1980). Sources of protein affecting the vit.B6 requirement of chicks.Poultry.Sci.,59:95-99.

Kazemi,R. and N.J.Daghir(1971). Interrelationships between methionine and vitamin B6 in chick diets. Poultry. Sci.,50:1296-1302.

Mamputu,M and R.J.Buhr (1995). Effect of substituting sesame meal for soybean meal on layer performance. Poultry Sci.,70:77.

Mandal,A.B.; A.V. Elangovan; P.K.Tyagi; S.Kaur;A.K.Johri (2006): Compatibility of using rapeseed and sunflower seed meal in maize sorghum soybean based diets for broiler chickens. Indian J.of Animal Sci.,76(9):741-737.

Mandlekar,S.M.(1992).Influence of dietary protein and amino acid supplementation on laying performance in egg type chickens. Poultry Adviser, 25(10):33-38. 
Mohan,B.; P.R.Reddy; D.Narahari and A.Thangavel (1990). Effect of feeding different vegetable protein on the performance of Japanese quail. Ind.J.Poulry.Sci.,25(3):178-182.

National Research Council (1994).Nutrient requirements of Poultry. $9^{\text {th }}$ rev.ed. National Academy Press Washington, D.C. U.S.A.

Rajesh,M.M; Reddy; P.S.Reddy and P.V.V.S.N.Reddy (2006). Effect of sunflower meal with or without enzyme supplementation on the performance of broiler. Tamilnadu- $\mathrm{J}$. of Veterinary and Animal Sci.,2(5):200-204.

Rama-Rao,S.V.; V.L.N.Rraju; S.M.Shailaja; and K.O.Murthy (2004). Effect of supplemental enzyme in diets containing yellow maize and pearl millet (Pennisetum typhoides) as the principle source of energy in broiler chicken. Anim.Nutri. and Feed Tech.,4:101-111.

Rama-Rao,S.V.; M.V.L.N.Rraju; A.K.Panda and M.R.Reddy (2006): Sunflower seed meal as a substitute for soybean meal in commercial broiler chicken diets. British Poultry Sci., Vol(5) pp.,592-598.

Rama-Rao,S.V.; M.V.L.NRaju; A.K.Panda; V.S. Poonam; G . Shyam Sunder and R. P. Sharma (2008): Utilization of sesame (Sesamum indicum) seed meal in broiler chicken diets. Brith. Poultry Sci., Vol. (49),81-85.

Ra-vindran,V. and R.Blair(1992).Feed resources for poultry production in Asia and the pacific.II.Plant protein sources. World Poult.Sci.J.,48:205231.

Reitman, S. and S. Frankel (1957). Calorimetric method for the determination of blood, aminotrnsferase enzymatic activities. Am. J. Clin. Pathol., 28: 56-63.

Sayed,M.A.(2002). Chemical and biochemical evaluation of sunflower meal and linseed meal in Poultry diets with reference to the effect on broiler performance. Egyp.Poulry.Sci.,(IV):953-965.

Senkoylu,N.;C.Polat; H.Akyurek;H.E.Samli;E.Erten and Z.Mikulec (1997). The effect of high energy high protein sunflower meal on broiler performance .Proceeding of the $11^{\text {th }}$ European WPSA symposium on poultry. Neutrino. Faaborg, Denmark,pp.,331-333.

Scott,M.L.; M.O. Nesheim and R.J.Young(1982). Nutrition of the chickens. ML. Scott and Associates. Ithaca New York.

Shrivastav,A.K. and T.S.Johri (2005). Effect of replacing soybean meal protein with sunflower seed meal in isonitrogenous diets on the performance of laying quails. Ind. J. of Poultry.Sci.,40(2):179-183.

Sohair,A.A; A.G.Abdallah and K.O.Abdel-Latif(2001). Influence of feeding allvegetable protein versus animal protein diets on performance, carcass characteristics and immune response of broiler chicks reared in hot climate. Egyp. J.Nut. and Feeds (4):991-1003.

SPSS for windows S, Chicago, IL SPSS $\AA$. Computer Software 14.00,(2005) SPSS Inc., Headquarters. Wacker Drive, Chicago, Illinois 60606, USA.233pp.

Tekeba,S.; R.P.Moudgal and Y.Alemu (2007). Compatibility of quality protein maize and sesame seed meals as a substitute for synthetic amino acid in broiler ration. The Afr. J.OF Life Sci.,Vol(1):No.2,pp.16-30. 
Tiwari,R.K.;R.P.S.Baghel and S.K. Singh (2005). Containing of Niger and sesame cake replacing soybean meal in coarse cereals based starter chicken ration. Ind.J.of Poultry.Sci., 40(3):241-244.

Tyagi,P.K.; A.V.Elangoran; P.K.Tyagi; S.kaur; A. Johari and A.B.Mandal (2003). Utilization sunflower seed meal along with maize or maize and pearl millet in the diets of broiler. Ind. J.of Poultry Sci,.38(3):248-243.

Valdivie,M.L; O.Sardinas and J.A. Garcia (1982). The utilization of $20 \%$ sunflower seed meal in broiler diets .Cuban J.Agri.Sci.,16(2):167-171.

Warnick G.R; J. Benderson; J.J Albers (1983). Dextran sulfate- Magnesium sup 2+precipitation procedure for quantitation of high-densitylipoprotein cholesterol. Sel. Methods Clin. Chem.;10:91-99.

Zollner, N. and K. Kirsch (1962). Total Lipids-Colorimetric Method. Z. Ges. Exp. Med, 135:545.

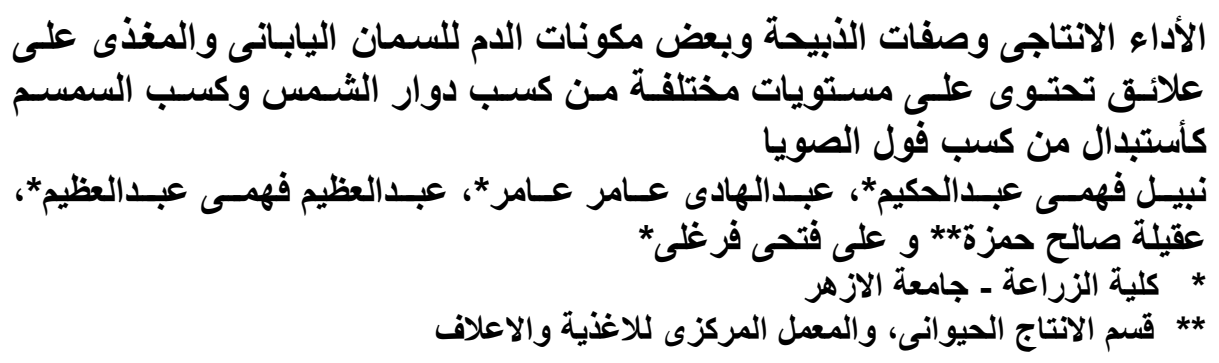

اجريت هذة التجربـة لبحث تأثير استبدال كسب فول الصويا بالاكسـاب الزيتيـة المحلية

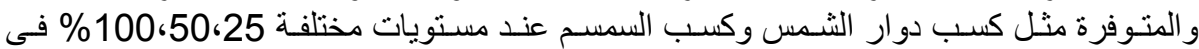

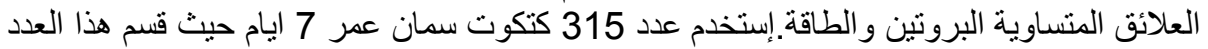

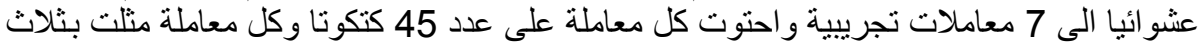

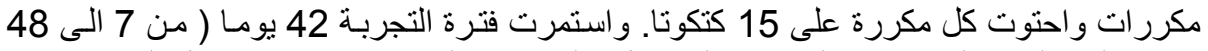

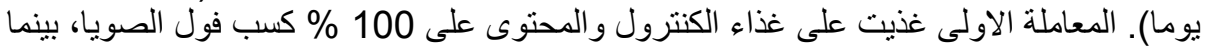

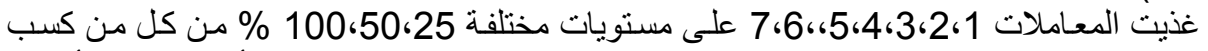

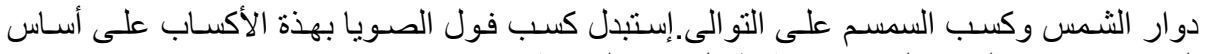
الوزن.ونم تقديم الماء و الغذاء بحرية طوال فترة التهب التجربة.

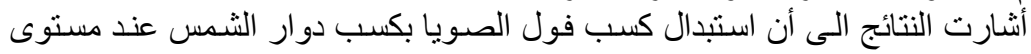

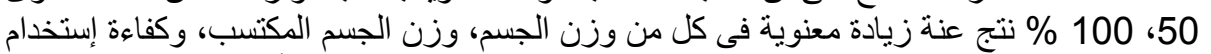

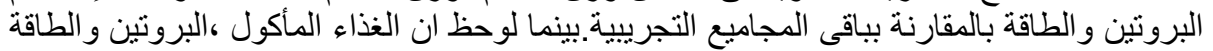

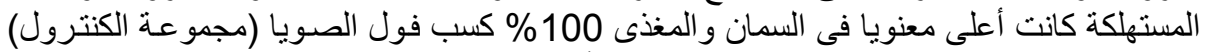

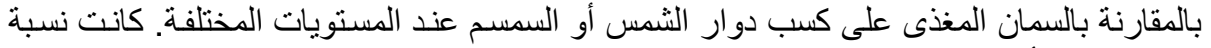

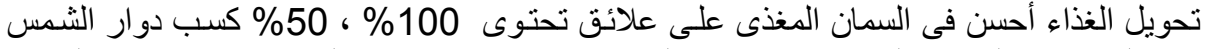

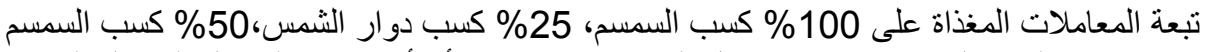

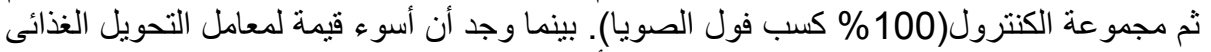

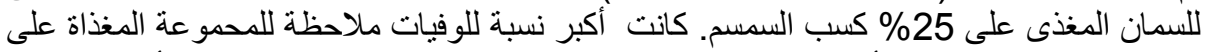

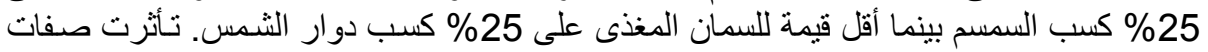

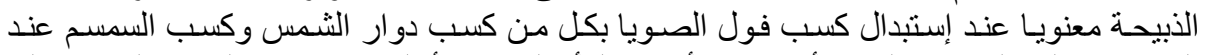
المسنويات المختلفة حيث لوحظ أن نسبة الأجزاء المأكولة كانت أعلى معنويا في السمان المغذى على لئى 


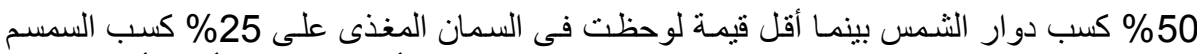
و المجموعة الكنترول(100\% كسب فول كول الصويا). وكانت نسبة الأجز اء الغير المأكولة أعلى معنويا

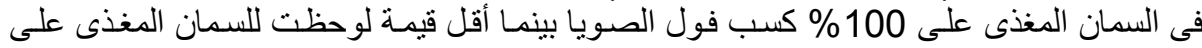

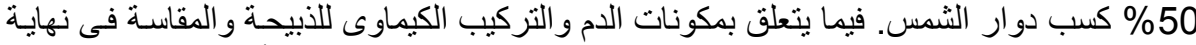

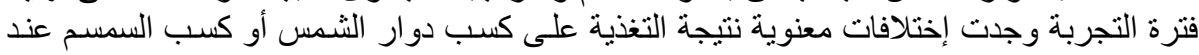

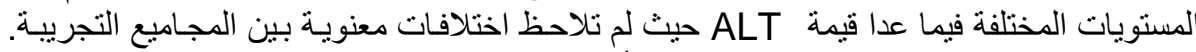

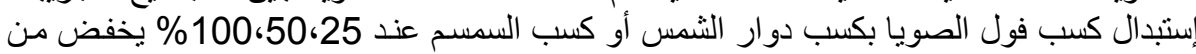
تكلفة الغذاء للطيور.

وعموما نستخلص من هذة الدر اسة وبناءا على النتائج المتحصل عليه أنة يمكن استبدال

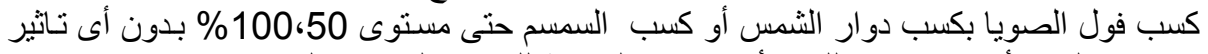

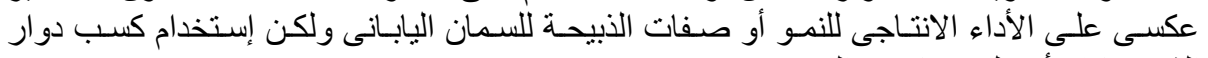
الثنمس كان أفضل من كسب الألمسم.

كلية الزراعة - جامعة المنصورة قام بتحكيم البحث مثم مركز البحوث الزراعية

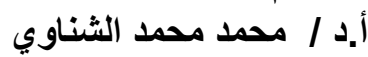
أ.د / أد ا فهمي الحسيني عبد السينام 
Table (3): Effect of replacing SBM by different levels of SFM and SSM on growth performance and mortality rate of Japanese quail (Means's \pm SE).

\begin{tabular}{|c|c|c|c|c|c|c|c|c|c|c|}
\hline Items & $\begin{array}{c}\text { Body } \\
\text { weight at } \\
7 \text { days }\end{array}$ & $\begin{array}{c}\text { Body } \\
\text { weight at } 48 \\
\text { days }\end{array}$ & $\begin{array}{l}\text { Body gain } \\
7-48 \text { days }\end{array}$ & $\begin{array}{l}\text { Feed } \\
\text { intake } \\
\text { g/bird/ } \\
\text { period }\end{array}$ & $\begin{array}{c}\text { Feed } \\
\text { conversion } \\
\text { ratio }\end{array}$ & $\begin{array}{l}\text { Protein } \\
\text { intake } \\
\text { g/bird/ } \\
\text { period }\end{array}$ & $\begin{array}{c}\text { Energy } \\
\text { intake } \\
\text { Kcal/bird/ } \\
\text { period }\end{array}$ & \begin{tabular}{|c|}
$\begin{array}{c}\text { Protein } \\
\text { efficiency } \\
\text { ratio }\end{array}$ \\
\end{tabular} & $\begin{array}{c}\begin{array}{c}\text { Energy } \\
\text { efficiency } \\
\text { ratio }\end{array} \\
\end{array}$ & $\begin{array}{c}\text { Mortality } \\
\text { rate \% }\end{array}$ \\
\hline \multicolumn{11}{|l|}{$\begin{array}{l}\text { Interaction among: } \\
\text { SBMXSMXSFM }^{*}\end{array}$} \\
\hline T1 (100\% SBM control) & $18.04 \pm 0.27$ & $178.16 \pm 0.17 f$ & $160.12 \pm 0.05 \mathrm{e}$ & $543 \pm 0.25 a$ & $3.39 \pm 0.006 b$ & $130.75 \pm 0.44 a$ & $1577.42 \pm 6.7 a$ & $1.22 \pm 0.005 \mathrm{e}$ & $10.15 \pm 0.08 \mathrm{e}$ & $6.66 \pm 0.35 d$ \\
\hline T2 (25\%SSM) & $17.99 \pm 0.39$ & $171.04 \pm 0.42 \mathrm{~g}$ & $153.05 \pm 0.03 \mathrm{~g}$ & $541 \pm 0.30 \mathrm{~b}$ & $3.53 \pm 0.003 a$ & $130.27 \pm 0.64 b$ & $1570.52 \pm 7.7 \mathrm{~b}$ & $1.18 \pm 0.003 f$ & $9.75 \pm 0.05 f$ & $8.66 \pm 0.33 b$ \\
\hline T3 (50\%SSM) & $17.82 \pm 0.31$ & $192.99 \pm 0.23 \mathrm{e}$ & $175.17 \pm 0.02 \mathrm{~d}$ & $525 \pm 0.26 \mathrm{c}$ & $2.99 \pm 0.004 \mathrm{c}$ & $126.08 \pm 0.48 \mathrm{c}$ & $1525.13 \pm 6.9 \mathrm{c}$ & $1.39 \pm 0.002 \mathrm{~d}$ & $11.48 \pm 0.06 \mathrm{~d}$ & $7.66 \pm 0.34 c$ \\
\hline T4 (100\% SSM) & $17.02 \pm 0.40$ & $203.75 \pm 0.40 \mathrm{c}$ & $186.73 \pm 0.08 b$ & $519 \pm 0.30 d$ & $2.78 \pm 0.002 \mathrm{e}$ & $125.13 \pm 0.64 d$ & $1507.18 \pm 5.7 d$ & $1.49 \pm 0.004 b$ & $12.39 \pm 0.05 \mathrm{~b}$ & $12.0 \pm 0.57 \mathrm{a}$ \\
\hline T5 (25\% SFM) & $16.94 \pm 0.42$ & $193.28 \pm 0.47 \mathrm{~d}$ & $176.34 \pm 0.04 \mathrm{c}$ & $517 \pm 0.47 \mathrm{e}$ & $2.93 \pm 0.003 \mathrm{~d}$ & $124.24 \pm 0.54 \mathrm{e}$ & $1500.32+8.6 \mathrm{e}$ & $1.42 \pm 0.001 c$ & $11.75 \pm 0.03 c$ & $5.60 \pm 0.30 \mathrm{e}$ \\
\hline T6 (50\% SFM) & $17.30 \pm 0.63$ & $206.50 \pm 0.42 a$ & $189.20 \pm 0.06 \mathrm{a}$ & $509 \pm 0.30 f$ & $2.69 \pm 0.007 f$ & $122.67 \pm 0.74 f$ & $1476.10 \pm 4.7 f$ & $1.54 \pm 0.003 a$ & $12.82 \pm 0.02 a$ & $6.66 \pm 0.31 d$ \\
\hline$T 7$ (100 SFM) & $16.93 \pm 0.40$ & $206.03 \pm 0.49 \mathrm{~b}$ & $189.10 \pm 0.07 a$ & $506 \pm 0.25 \mathrm{~g}$ & $2.68 \pm 0.005 f$ & $122.45 \pm 0.63 \mathrm{~g}$ & $1469.42 \pm 5.6 \mathrm{~g}$ & $1.54 \pm 0.002 \mathrm{a}$ & $12.87 \pm 0.02 \mathrm{a}$ & $6.66 \pm 0.29 \mathrm{~d}$ \\
\hline Overall mean & $17.44 \pm 0.41$ & $193.11 \pm 2.0$ & $175.67 \pm 2.07$ & $522 \pm 2.10$ & $2.99 \pm 0.06$ & $125.63 \pm 0.61$ & $1514.42 \pm 7.61$ & $1.40 \pm 0.03$ & $11.62 \pm 0.05$ & $7.69 \pm 0.30$ \\
\hline Significant effect & NS & & & 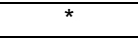 & & 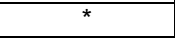 & 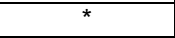 & & 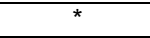 & 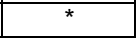 \\
\hline \multicolumn{11}{|l|}{ Sources: } \\
\hline SBM & $18.04 \pm 0.27$ & $178.16 \pm 0.17 \mathrm{c}$ & $160.12+0.05 c$ & $543 \pm 0.25 a$ & $3.39 \pm 0.006 \mathrm{a}$ & $130.75 \pm 0.44 a$ & $1577.42 \pm 6.7 a$ & $1.23 \pm 0.005 \mathrm{c}$ & $10.15 \pm 0.08 \mathrm{c}$ & $6.66 \pm 0.35 b$ \\
\hline SFM & $17.61 \pm 0.22$ & $201.93 \pm 1.4 a$ & $184.32+1.4 a$ & $510 \pm 0.20 \mathrm{c}$ & $2.77 \pm 0.004 \mathrm{c}$ & $123.12 \pm 0.69 \mathrm{~b}$ & $1481.95 \pm 4.8 \mathrm{c}$ & $1.50 \pm 0.003 a$ & $\pm 0.18 \mathrm{a}$ & $6.30 \pm 0.29 c$ \\
\hline SSM & $17.06 \pm 0.28$ & $189.25 \pm 3.2 b$ & $172.19 \pm 3.3 b$ & $528 \pm 0.29 b$ & $3.06 \pm 0.002 b$ & $126.6 \pm 0.55 \mathrm{c}$ & $1527.83 \pm 6.6 \mathrm{~b}$ & $1.36 \pm 0.004 b$ & $11.24 \pm 0.37 \mathrm{~b}$ & $9.43 \pm 0.33 a$ \\
\hline Overall mean & $17.44 \pm 0.41$ & $193.11 \pm 2.0$ & $175.67 \pm 2.07$ & $522 \pm 2.10$ & $2.99 \pm 0.06$ & $125.63 \pm 0.61$ & $1514.42 \pm 7.61$ & $1.40 \pm 0.03$ & $11.62 \pm 0.05$ & $7.69 \pm 0.30$ \\
\hline Significant effect & NS & 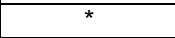 & & 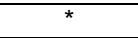 & 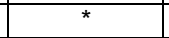 & 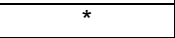 & 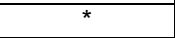 & 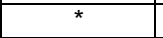 & 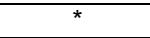 & 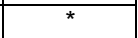 \\
\hline \multicolumn{11}{|l|}{ Levels (\%): } \\
\hline 100 (control) & $18.04 \pm 0.27$ & $178.16 \pm 0.17 d$ & $160.12 \pm 0.06 \mathrm{~d}$ & $543 \pm 0.25 a$ & $3.39 \pm 0.006 \mathrm{a}$ & $130.75 \pm 0.44 a$ & $1577.42 \pm 6.7 \mathrm{a}$ & $1.23 \pm 0.005 \mathrm{~d}$ & $10.15 \pm 0.08 d$ & $6.66 \pm 0.35 d$ \\
\hline 25 & $17.46 \pm 0.29$ & $182.16 \pm 3.3 c$ & $164.70 \pm 3.3 \mathrm{c}$ & $530 \pm 3.06 b$ & $3.21 \pm 0.005 b$ & $126.41 \pm 0.50 \mathrm{~b}$ & $1525.26 \pm 11.7 \mathrm{~b}$ & $1.30 \pm 0.003 \mathrm{c}$ & & $7.13 \pm 0.70 c$ \\
\hline 50 & $17.56 \pm 0.35$ & $199.02+2.0 \mathrm{~b}$ & $182.19 \pm 2.1 \mathrm{~b}$ & $516+2.44 c$ & $2.84 \pm 0.005 \mathrm{c}$ & $124.38 \pm 0.77 \mathrm{c}$ & $1501.09 \pm 11.2 \mathrm{c}$ & $1.46 \pm 0.002 \mathrm{~b}$ & $12.09 \pm 0.50 \mathrm{~b}$ & $7.15 \pm 0.77 \mathrm{~b}$ \\
\hline 100 & $16.98 \pm 0.16$ & $204.41 \pm 0.35 a$ & $187.43 \pm 0.35 a$ & $512 \pm 1.99 d$ & $2.73 \pm 0.002 \mathrm{~d}$ & $123.79 \pm 0.61 d$ & $1488.30 \pm 8.5 d$ & $1.52 \pm 0.007 \mathrm{a}$ & $12.59 \pm 0.11 \mathrm{a}$ & $9.33 \pm 0.61 \mathrm{a}$ \\
\hline Overall mean & $17.44 \pm 0.41$ & $193.11 \pm 2.0$ & $175.67 \pm 2.07$ & $522 \pm 2.10$ & $2.99 \pm 0.06$ & $125.63 \pm 0.61$ & $1514.42 \pm 7.61$ & $1.40 \pm 0.03$ & $11.62 \pm 0.05$ & $7.69 \pm 0.30$ \\
\hline Significant effect & NS & * & * & * & * & * & * & * & * & * \\
\hline
\end{tabular}

a,b,c....Means in the same column have the different superscript are significantly different at $(p \leq 0.05)$.

*SBM=Soybean meal, SSM=Sesame meal, SFM=Sunflower meal. 
Table (4): Effect of replacing SBM by different levels of SFM and SSM on body chemical composition (on dray matter basis \%) of Japanese quail at the end of experimental period (Means $\pm \mathrm{SE}$ ).

\begin{tabular}{|c|c|c|c|c|c|c|}
\hline \begin{tabular}{|ll} 
Effects & Itemss \\
\end{tabular} & Moisture\% & DM\% & СР\% & EE\% & Ash\% & NFE\% \\
\hline $\begin{array}{l}\text { Interaction among: } \\
\text { Sbmxsmxsfm }\end{array}$ & & & & & & \\
\hline \begin{tabular}{|l} 
T1 (100\% SBM control $)^{\star}$ \\
T2 (25\% SSM) \\
T3 (50\%SSM) \\
T4 (100\% SSM) \\
T5 (25\% SFM) \\
T6 (50\% SFM) \\
T7 (100 SFM) \\
\end{tabular} & $\begin{array}{c}68.94 \pm 0.98 b \\
67.64 \pm 0.42 c \\
66.83 \pm 0.73 d \\
67.56 \pm 0.66 \mathrm{c} \\
69.04 \pm 0.47 \mathrm{~b} \\
67.08 \pm 0.92 \mathrm{~cd} \\
69.79 \pm 0.42 \mathrm{a} \\
\end{array}$ & $\begin{array}{l}31.06 \pm 0.07 \mathrm{e} \\
32.36 \pm 0.05 \mathrm{~d} \\
33.17 \pm 0.02 \mathrm{a} \\
32.44 \pm 0.07 \mathrm{c} \\
30.96 \pm 0.04 \mathrm{f} \\
32.92 \pm 0.03 \mathrm{~b} \\
30.21 \pm 0.01 \mathrm{~g} \\
\end{array}$ & $\begin{array}{l}65.98 \pm 0.16 \mathrm{c} \\
63.85 \pm 0.14 \mathrm{f} \\
65.37 \pm 0.13 \mathrm{e} \\
65.96 \pm 0.11 \mathrm{c} \\
66.75 \pm 0.13 \mathrm{a} \\
66.14 \pm 0.11 \mathrm{~b} \\
65.83 \pm 0.67 \mathrm{~d} \\
\end{array}$ & $\begin{array}{l}28.32 \pm 0.05 \mathrm{~d} \\
30.80 \pm 0.06 \mathrm{a} \\
29.07 \pm 0.04 \mathrm{c} \\
29.13 \pm 0.01 \mathrm{~b} \\
27.17 \pm 0.02 \mathrm{e} \\
26.42 \pm 0.01 \mathrm{f} \\
26.07 \pm 0.03 \mathrm{~g}\end{array}$ & $\begin{array}{l}4.82 \pm 0.01 \mathrm{~d} \\
4.77 \pm 0.02 \mathrm{e} \\
4.81 \pm 0.07 \mathrm{~d} \\
4.53 \pm 0.05 \mathrm{f} \\
4.96 \pm 0.03 \mathrm{c} \\
5.80 \pm 0.01 \mathrm{~b} \\
6.93 \pm 0.02 \mathrm{a} \\
\end{array}$ & $\begin{array}{l}0.88 \pm 0.005 \mathrm{~d} \\
0.58 \pm 0.003 \mathrm{f} \\
0.75 \pm 0.004 \mathrm{e} \\
0.38 \pm 0.004 \mathrm{~g} \\
1.12 \pm 0.002 \mathrm{c} \\
1.64 \pm 0.01 \mathrm{a} \\
1.17 \pm 0.03 \mathrm{~b} \\
\end{array}$ \\
\hline Overall mean & $68.13 \pm 0.18$ & $31.67 \pm 0.06$ & $65.69 \pm 0.13$ & $28.14 \pm 0.04$ & $5.23 \pm 0.03$ & $0.94 \pm 0.006$ \\
\hline Significant effect & * & * & * & * & * & * \\
\hline $\begin{array}{c}\text { Sources: } \\
\text { SBM } \\
\text { SFM } \\
\text { SM } \\
\end{array}$ & $\begin{array}{l}68.94 \pm 0.98 a \\
68.64 \pm 0.28 a \\
67.34 \pm 0.22 b \\
\end{array}$ & $\begin{array}{l}31.06 \pm 0.06 \mathrm{c} \\
31.36 \pm 0.07 \mathrm{~b} \\
32.66 \pm 0.03 \mathrm{a} \\
\end{array}$ & $\begin{array}{l}65.98 \pm 0.16 \mathrm{~b} \\
66.24 \pm 0.14 \mathrm{a} \\
65.06 \pm 0.12 \mathrm{c} \\
\end{array}$ & $\begin{array}{l}28.32 \pm 0.05 b \\
26.55 \pm 0.03 c \\
29.66 \pm 0.05 a \\
\end{array}$ & $\begin{array}{l}4.82 \pm 0.01 b \\
5.89 \pm 0.04 a \\
4.71 \pm 0.03 c\end{array}$ & $\begin{array}{l}0.88 \pm 0.005 b \\
1.32 \pm 0.009 a \\
0.57 \pm 0.003 c\end{array}$ \\
\hline Overall mean & $68.13 \pm 0.18$ & $31.67 \pm 0.06$ & $65.69 \pm 0.13$ & $28.14 \pm 0.24$ & $5.23 \pm 0.03$ & $0.94 \pm 0.006$ \\
\hline Significant effect & & * & * & * & * & * \\
\hline $\begin{array}{c}\text { Levels (\%): } \\
100 \text { (control) } \\
25 \\
50 \\
100 \\
\end{array}$ & $\begin{array}{r}68.94 \pm 0.98 a \\
68.34 \pm 0.21 b \\
66.95 \pm 0.37 \mathrm{c} \\
68.68 \pm 0.46 \mathrm{ab} \\
\end{array}$ & $\begin{array}{r}31.06 \pm 0.6 \mathrm{~d} \\
31.66 \pm 0.01 \mathrm{~b} \\
33.05 \pm 0.04 \mathrm{a} \\
31.32 \pm 0.03 \mathrm{c} \\
\end{array}$ & $\begin{array}{l}65.98 \pm 0.16 a \\
65.30 \pm 0.13 d \\
65.75 \pm 0.12 c \\
65.90 \pm 0.11 b \\
\end{array}$ & $\begin{array}{l}28.32 \pm 0.05 b \\
28.98 \pm 0.04 a \\
27.75 \pm 0.02 c \\
27.60 \pm 0.06 d \\
\end{array}$ & $\begin{array}{l}4.82 \pm 0.01 d \\
4.87 \pm 0.05 \mathrm{c} \\
5.31 \pm 0.05 \mathrm{~b} \\
5.73 \pm 0.06 \mathrm{a} \\
\end{array}$ & $\begin{array}{c}0.88 \pm 0.005 b \\
0.85 \pm 0.008 c \\
1.19 \pm 0.03 a \\
0.77 \pm 0.004 d \\
\end{array}$ \\
\hline Overall mean & $68.13 \pm 0.18$ & $31.67 \pm 0.06$ & $65.69 \pm 0.13$ & $28.14 \pm 0.04$ & $5.23 \pm 0.03$ & $0.94 \pm 0.006$ \\
\hline Significant effect & & * & * & * & * & * \\
\hline $\begin{array}{c}\frac{\text { sex }}{\text { Males }} \\
\text { Females }\end{array}$ & $\begin{array}{l}67.91 \pm 0.28 b \\
68.34 \pm 0.23 a\end{array}$ & $\begin{array}{l}32.09 \pm 0.05 \\
31.66 \pm 0.06\end{array}$ & $\begin{array}{l}65.70 \pm 0.13 \\
65.69 \pm 0.12\end{array}$ & $\begin{array}{l}28.14 \pm 0.05 \\
28.13 \pm 0.04\end{array}$ & $\begin{array}{l}5.23 \pm 0.03 \\
5.24 \pm 0.04\end{array}$ & $\begin{array}{l}0.94 \pm 0.008 \\
0.94 \pm 0.008\end{array}$ \\
\hline Overall mean & $68.13 \pm 0.18$ & $31.67 \pm 0.06$ & $65.69 \pm 0.13$ & $28.14 \pm 0.04$ & $5.23 \pm 0.03$ & $0.94 \pm 0.006$ \\
\hline Significant effect & & NS & NS & NS & NS & NS \\
\hline
\end{tabular}

Significant effect NS NS NS

- Means in the same column have the different superscript 
J. Animal and Poultry Prod., Mansoura Univ., Vol. 2 (6), June,2011

Table (5): Effect of replacing SBM by different levels of SFM and SSM on relative carcass characteristics of Japanese quail. at the end of experimental period(Means $\pm S E$ ).

\begin{tabular}{|c|c|c|c|c|c|c|c|c|}
\hline \multirow[b]{2}{*}{ Effects } & \multicolumn{8}{|c|}{ Carcass characteristics relative to body weight $\%$} \\
\hline & $\begin{array}{l}\text { Live body } \\
\text { weight }\end{array}$ & Liver & Gizzard & Heart & Edible parts & Dressing & $\begin{array}{c}\text { Total edible } \\
\text { parts }\end{array}$ & $\begin{array}{c}\text { Total inedible } \\
\text { parts }^{1}\end{array}$ \\
\hline \begin{tabular}{|l|l|}
$\begin{array}{l}\text { Interaction } \\
\text { SBMxSFMxSSM }\end{array}$ & among \\
\end{tabular} & & & & & & & & \\
\hline \begin{tabular}{|c|} 
T1 (100\% SBM \\
control) \\
T2 (25\% SSM) \\
T3 (50\% SSM) \\
T4 (100\% SSM) \\
T5 (25\% SFM) \\
T6 (50\% SFM) \\
T7 (100 \% SFM)
\end{tabular} & $\begin{array}{l}183.33 \pm 0.67 d \\
183.71 \pm 0.76 d \\
192.65 \pm 0.70 c \\
195.53 \pm 0.69 b \\
195.96 \pm 0.49 b \\
195.01 \pm 0.44 b \\
211.85 \pm 0.32 a\end{array}$ & $\begin{array}{c}2.45 \pm 0.09 c d \\
2.17 \pm 0.03 \mathrm{e} \\
2.80 \pm 0.03 \mathrm{a} \\
1.73 \pm 0.06 f \\
2.73 \pm .03 \mathrm{~b} \\
2.32 \pm 0.06 \mathrm{~d} \\
2.48 \pm 0.03 \mathrm{c}\end{array}$ & $\begin{array}{l}1.73 \pm 0.02 \mathrm{c} \\
1.52 \pm 0.06 \mathrm{f} \\
1.71 \pm 0.02 \mathrm{~d} \\
1.75 \pm 0.02 \mathrm{~b} \\
1.74 \pm 0.02 \mathrm{~b} \\
1.86 \pm 0.03 \mathrm{a} \\
1.60 \pm 0.02 \mathrm{e}\end{array}$ & $\begin{array}{l}0.95 \pm 0.002 b \\
0.88 \pm 0.003 d \\
0.93 \pm 0.002 c \\
0.95 \pm 0.002 b \\
0.82 \pm 0.003 e \\
0.96 \pm 0.003 a \\
0.88 \pm 0.002 d\end{array}$ & \begin{tabular}{|c|}
$5.13 \pm 0.06 \mathrm{c}$ \\
$4.57 \pm 0.03 \mathrm{e}$ \\
$5.44 \pm 0.01 \mathrm{a}$ \\
$4.43 \pm 0.04 \mathrm{f}$ \\
$5.29 \pm 0.05 \mathrm{~b}$ \\
$5.14 \pm 0.03 \mathrm{c}$ \\
$4.96 \pm .02 \mathrm{~d}$
\end{tabular} & \begin{tabular}{|l|}
$64.87 \pm 6.14 \mathrm{~g}$ \\
$66.25 \pm 4.28 \mathrm{e}$ \\
$65.73 \pm 4.28 \mathrm{f}$ \\
$67.39 \pm 4.22 \mathrm{~d}$ \\
$67.43 \pm 2.58 \mathrm{c}$ \\
$67.93 \pm 4.28 \mathrm{a}$ \\
$67.81 \pm 4.22 \mathrm{~b}$
\end{tabular} & $\begin{array}{c}70.02 \pm 7.92 \mathrm{~g} \\
70.82 \pm 3.65 \mathrm{f} \\
71.16 \pm 4.01 \mathrm{e} \\
71.82 \pm 7.92 \mathrm{~d} \\
72.81 \pm 2.24 \mathrm{~b} \\
73.07 \pm 3.65 \mathrm{a} \\
72.77 \pm 4.28 \mathrm{c}\end{array}$ & $\begin{array}{l}29.98 \pm 0.21 \mathrm{a} \\
29.18 \pm 0.22 \mathrm{~b} \\
28.83 \pm 0.33 \mathrm{c} \\
28.18 \pm 0.37 \mathrm{~d} \\
27.19 \pm 0.31 \mathrm{f} \\
26.93 \pm 0.34 \mathrm{~g} \\
27.23 \pm 0.21 \mathrm{e}\end{array}$ \\
\hline Overall mean & $193.92 \pm 0.43$ & $2.39 \pm 0.05$ & $1.70 \pm 0.02$ & $0.91 \pm 0.007$ & $4.99 \pm 0.05$ & $66.77 \pm 0.17$ & $71.78 \pm 0.17$ & $28.22 \pm 0.28$ \\
\hline Significant effect & $\star \star$ & 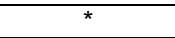 & & $*$ & $\star *$ & & & $*$ \\
\hline Sources & & & & & & & & \\
\hline $\begin{array}{l}\text { SBM } \\
\text { SFM } \\
\text { SSM }\end{array}$ & $\begin{array}{l}183.39 \pm 0.67 c \\
200.67 \pm 0.38 a \\
190.67 \pm 0.42 b\end{array}$ & $\begin{array}{l}2.45 \pm 0.09 \mathrm{~b} \\
2.53 \pm 0.04 \mathrm{a} \\
2.23 \pm 0.11 \mathrm{c} \\
\end{array}$ & $\begin{array}{l}1.73 \pm 0.02 \mathrm{a} \\
1.74 \pm 0.03 \mathrm{a} \\
1.65 \pm 0.02 \mathrm{~b}\end{array}$ & $\begin{array}{l}0.95 \pm 0.002 a \\
0.88 \pm 0.001 c \\
0.92 \pm 0.006 b \\
\end{array}$ & \begin{tabular}{|c|}
$5.12 \pm 0.06 \mathrm{a}$ \\
$5.13 \pm 0.04 \mathrm{a}$ \\
$4.81 \pm 0.1 \mathrm{~b}$ \\
\end{tabular} & $\begin{array}{l}64.87 \pm 6.14 c \\
67.73 \pm 3.55 a \\
66.45 \pm 3.36 b \\
\end{array}$ & $\begin{array}{l}70.02 \pm 7.92 \mathrm{c} \\
72.88 \pm 3.55 \mathrm{a} \\
71.26 \pm 3.66 \mathrm{~b} \\
\end{array}$ & $\begin{array}{l}29.98 \pm 0.21 a \\
27.12 \pm 0.39 c \\
28.73 \pm 0.23 b\end{array}$ \\
\hline Overall mean & $193.92 \pm 0.43$ & $2.39 \pm 0.05$ & $1.70 \pm 0.02$ & $0.91 \pm 0.007$ & $4.99 \pm 0.05$ & $66.77 \pm 0.17$ & $71.78 \pm 0.17$ & $28.22 \pm 0.28$ \\
\hline Significant effect & 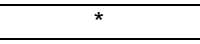 & * & $+x^{*}$ & 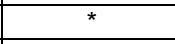 & 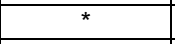 & 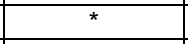 & 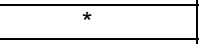 & 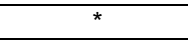 \\
\hline Levels (\%): & & & & & & & & \\
\hline $\begin{array}{c}100 \text { (control) } \\
25 \\
50 \\
100 \\
\end{array}$ & $\begin{array}{l}183.39 \pm 0.67 d \\
189.84 \pm 0.44 c \\
193.89 \pm 0.34 b \\
203.28 \pm 0.34 a \\
\end{array}$ & $\begin{array}{l}2.46 \pm 0.09 \mathrm{~b} \\
2.45 \pm 0.08 \mathrm{~b} \\
2.59 \pm 0.07 \mathrm{a} \\
2.11 \pm 0.11 \mathrm{c} \\
\end{array}$ & $\begin{array}{l}1.73 \pm 0.02 \mathrm{~b} \\
1.63 \pm 0.03 \mathrm{~d} \\
1.78 \pm 0.02 \mathrm{a} \\
1.67 \pm 0.02 \mathrm{c} \\
\end{array}$ & $\begin{array}{l}0.95 \pm 0.002 a \\
0.85 \pm 0.008 c \\
0.94 \pm 0.005 a \\
0.91 \pm 0.001 b \\
\end{array}$ & \begin{tabular}{|l|}
$5.12 \pm 0.06 \mathrm{~b}$ \\
$4.93 \pm 0.11 \mathrm{c}$ \\
$5.28 \pm 0.04 \mathrm{a}$ \\
$4.69 \pm 0.08 \mathrm{~d}$ \\
\end{tabular} & $\begin{array}{l}64.87 \pm 6.14 \mathrm{~d} \\
66.84 \pm 3.15 \mathrm{~b} \\
66.82 \pm 3.33 \mathrm{c} \\
67.60 \pm 3.66 \mathrm{a} \\
\end{array}$ & $\begin{array}{c}70.02 \pm 7.92 \mathrm{~d} \\
71.81 \pm 2.30 \mathrm{c} \\
72.12 \pm 3.28 \mathrm{~b} \\
72.29 \pm 3.14 \mathrm{a} \\
\end{array}$ & $\begin{array}{l}29.98 \pm 0.21 a \\
28.19 \pm 0.57 b \\
27.88 \pm 0.51 c \\
27.71 \pm 0.29 d \\
\end{array}$ \\
\hline Overall mean & $193.92 \pm 0.43$ & $2.39 \pm 0.05$ & $1.70 \pm 0.02$ & $0.91 \pm 0.007$ & $4.99 \pm 0.05$ & $66.77 \pm 0.17$ & $71.78 \pm 0.17$ & $28.22 \pm 0.28$ \\
\hline Significant effect & $t$ & $t$ & * & * & * & * & * & * \\
\hline $\begin{array}{c}\text { sex } \\
\text { Male } \\
\text { Female }\end{array}$ & $\begin{array}{l}193.99 \pm 0.46 \\
193.84 \pm 0.44\end{array}$ & $\begin{array}{l}2.38 \pm 0.07 \\
2.40 \pm 0.08 \\
\end{array}$ & $\begin{array}{l}1.70 \pm 0.03 \\
1.70 \pm 0.02 \\
\end{array}$ & $\begin{array}{l}0.91 \pm 0.001 \\
0.90 \pm 0.002 \\
\end{array}$ & $\begin{array}{l}4.99 \pm 0.07 \\
4.99 \pm 0.08 \\
\end{array}$ & $\begin{array}{l}66.77 \pm 3.34 \\
63.75 \pm 2.34 \\
\end{array}$ & $\begin{array}{l}71.79 \pm 3.71 \\
71.77 \pm 3.64 \\
\end{array}$ & $\begin{array}{l}28.22 \pm 0.40 \\
28.22 \pm 0.40 \\
\end{array}$ \\
\hline Overall mean & $193.92 \pm 0.43$ & $2.39 \pm 0.05$ & $1.70 \pm 0.02$ & $0.91 \pm 0.007$ & $4.99 \pm 0.05$ & $66.77 \pm 0.17$ & $71.78 \pm 017$ & $28.22 \pm 0.28$ \\
\hline Significant effect & 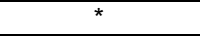 & NS & NS & NS & NS & NS & NS & NS \\
\hline
\end{tabular}

column have the different superscript are

*SBM=Soybean meal, SSM=Sesame meal, SFM=Sunflower meal.

1-Total inedible parts including blood, feather, head, neck, wing, legs and intestine 
Abdel-Hakim, N. F. et al.

1-Accodring to the price of different ingredients available in Egypt at 2009

\begin{tabular}{|c|c|c|c|c|c|c|c|}
\hline \multirow[b]{2}{*}{ Items } & \multicolumn{7}{|c|}{ Treatments } \\
\hline & $\begin{array}{c}\text { T1 } \\
100 \% \text { SBM } \\
\text { (control) }\end{array}$ & $\begin{array}{c}\text { T2 } \\
25 \% S S M\end{array}$ & $\begin{array}{c}\text { T3 } \\
50 \% \text { SSM }\end{array}$ & $\begin{array}{c}\text { T4 } \\
100 \% \text { SSM }\end{array}$ & $\begin{array}{c}\text { T5 } \\
25 \% S F M\end{array}$ & $\begin{array}{c}\text { T6 } \\
50 \% S F M\end{array}$ & $\begin{array}{c}\text { T7 } \\
100 \% \text { SFM }\end{array}$ \\
\hline Initial body weight g/bird. & $180.04 \pm 0.27$ & $17.99 \pm 0.39$ & $17.82 \pm .39$ & $17.02 \pm 0.31$ & $16.94 \pm 0.42$ & $17.30 \pm 0.63$ & $16.93 \pm 0.40$ \\
\hline Final body weight g/bird. & $178.16 \pm 0.17 f$ & $171.04 \pm 0.42 \mathrm{~g}$ & $192.99 \pm 0.23 e$ & $203.75 \pm 0.40 \mathrm{c}$ & $193.28 \pm 0.47 d$ & $206.50 \pm 0.42 a$ & $206.03 \pm 0.49 \mathrm{a}$ \\
\hline Total amount of feed intake/g/bird/period. & $543 \pm 0.25 a$ & $541 \pm 0.30 b$ & $525 \pm 0.26 c$ & $519 \pm 0.30 d$ & $517 \pm 0.47 \mathrm{e}$ & $509 \pm 0.30 f$ & $506 \pm 0.25 g$ \\
\hline Feed $\operatorname{cost}(\mathrm{PT}) /$ chick $^{1}$ & 0.90 & 0.89 & 0.87 & 0.85 & 0.85 & 0.84 & 0.84 \\
\hline Price of chick at 1 day of age (PT) ${ }^{2}$. & 0.50 & 0.50 & 0.50 & 0.50 & 0.50 & 0.50 & 0.50 \\
\hline Total cost $(\mathrm{PT}) /$ chick & 1.40 & 1.39 & 1.37 & 1.35 & 1.35 & 1.34 & 1.34 \\
\hline Total revenue $(\mathrm{PT}) /$ chick $^{3}$ & 2.67 & 2.57 & 2.9 & 3.06 & 2.90 & 3.09 & 3.09 \\
\hline Net revenue(PT)/chick & 1.27 & 1.18 & 1.53 & 1.71 & 1.55 & 1.75 & 1.75 \\
\hline Relative economic efficiency\% & 90.71 & 84.89 & 111.68 & 26.67 & 114.82 & 130.60 & 130.60 \\
\hline Control ${ }^{5}$ & 100 & 93.58 & 123.12 & 139.65 & 126.58 & 143.98 & 143.98 \\
\hline
\end{tabular}

\section{2-Fixed cost}

3-Price of $1 \mathrm{~kg}$ live weight=15 LE.

4-Net revenue per unit total cost

5-Assuming that the relative economical efficiency of control group equals $100 \%$. 
Table (6): Effect of replacing SBM by different levels of SFM and SSM on blood plasma constituents of Japanese quail at the end of experimental period (Means's $\pm S E$ ).

\begin{tabular}{|c|c|c|c|c|c|c|c|c|c|c|c|}
\hline 1 & \begin{tabular}{|c|} 
Total \\
plasma \\
protein \\
(mg/d)
\end{tabular} & $\begin{array}{c}\text { Total } \\
\text { plasma } \\
\text { albumin } \\
\text { (mg/d) }\end{array}$ & $\begin{array}{c}\text { Total } \\
\text { plasma } \\
\text { globulin } \\
(\mathrm{mg} / \mathrm{d})\end{array}$ & $\begin{array}{l}A G G \\
\text { ratio }\end{array}$ & $\begin{array}{c}\text { Total } \\
\text { plasma } \\
\text { lipids } \\
\text { (mg/d) }\end{array}$ & \begin{tabular}{|} 
Total plasma \\
Triglycerides \\
( mg/d)
\end{tabular} & $\begin{array}{c}\text { Total plasma } \\
\text { cholesterol } \\
\text { (mg/d) }\end{array}$ & $\begin{array}{c}\text { Total } \\
\text { Plasma } \\
\text { HDL } \\
\text { (mg/d) }\end{array}$ & $\begin{array}{c}\text { Total } \\
\text { plasma } \\
\text { LDL(mg/d) }\end{array}$ & $\begin{array}{l}\text { AST } \\
(\mathrm{U} / \mathrm{ml})^{1}\end{array}$ & $\begin{array}{c}\text { ALT } \\
(\mathrm{U} / \mathrm{m})^{2}\end{array}$ \\
\hline \multicolumn{12}{|l|}{$\begin{array}{l}\text { Interactionamong: } \\
\text { SBMXSMXSFM* }\end{array}$} \\
\hline T1 (100\% SBMcontrol) & $4.29 \pm 0.08 \mathrm{~d}$ & $215 \pm 0.03 d$ & $214 \pm 0.07 \mathrm{e}$ & $1.01 \pm 0.04 a b$ & $857.41+2293 a$ & $10828+3.54 a$ & $209.14 \pm 5.02 a$ & $66.40 \pm 221 a$ & $67.63+8.820$ & $89.16 \pm 9.34 a$ & $27.83+283$ \\
\hline T2 (25\%SSM) & $5.22+0.18 b c$ & $275 \pm 0.15 b c$ & $247 \pm 0.15 d$ & $1.14 \pm 0.11 a$ & $659.68+55.31 b$ & $80.43+3.13 b$ & $14284 \pm 6.490$ & $5323 \pm 1.13 b$ & $109.39+9.17 a$ & $32.16+216 \mathrm{~b}$ & $25.0 \pm 0.0$ \\
\hline T3 (50\%SSM) & $5.03+0.12 \mathrm{c}$ & $262+0.11 \mathrm{c}$ & $241 \pm 0.10 d$ & $1.03 \pm 0.07 a b$ & $72243+47.026$ & $78.33+3.57 \mathrm{bc}$ & $150.68+3.91 \mathrm{~b}$ & $50.86 \pm 1.98 b$ & $105.72+9.04 a$ & $36.50+290 \mathrm{~b}$ & $25.0 \pm 0.0$ \\
\hline T4(100\%SSM) & $5.54 \pm 0.10 \mathrm{ab}$ & $294 \pm 0.07 a b$ & $259+0.040 \mathrm{~d}$ & $1.13 \pm 0.02 \mathrm{a}$ & $631.81 \pm 44.84 \mathrm{~b}$ & $69.75 \pm 3.33 c$ & $151.99 \pm 5.75 b$ & $48.51+211 b c$ & $106.74 \pm 13.02 \mathrm{a}$ & $34.33+274 b$ & $25.0 \pm 0.0$ \\
\hline T5(25\%SFM) & $5.61 \pm 0.15 a$ & $3.03 \pm 0.05 a$ & $284 \pm 0.10 \mathrm{bc}$ & $0.98+0.08 \mathrm{ab}$ & $593.15 \pm 61.08 \mathrm{~b}$ & $67.65 \pm 3.57 \mathrm{c}$ & 146.45 $\pm 5.11 \mathrm{~b}$ & $44.29 \pm 1.350 \mathrm{~d}$ & $113.26+14.10 a$ & $34.33+274 b$ & $27.83+283$ \\
\hline T6(50\%SFM) & $5.69 \pm 0.10 \mathrm{a}$ & $3.02+0.05 a$ & $3.02+0.05 \mathrm{ab}$ & $0.88 \pm 0.04 b$ & $690.11 \pm 34.59 \mathrm{~b}$ & $73.02+4.02 b c$ & $147.26+4.47 \mathrm{~b}$ & $4239 \pm 1.04 d$ & $103.68+5.35 a$ & $30.0 \pm 0.0 \mathrm{~b}$ & $27.83+283$ \\
\hline$T 7$ (100SFM) & $5.83 \pm 0.13 a$ & $3.12+0.02 a$ & $3.12+0.02 a$ & $0.86 \pm 0.02 b$ & $656.52+34.39 \mathrm{~b}$ & $67.59+3.74 c$ & $131.82+6.47 \mathrm{~b}$ & $4234 \pm 1.17 d$ & $103.27 \pm 5.82 a$ & $34.33+274 b$ & $23.16+1.83$ \\
\hline Overallmean & \begin{tabular}{|l|}
$5.32+0.08$ \\
\end{tabular} & $280 \pm 0.05$ & $265 \pm 0.06$ & $1.0 \pm 0.02$ & \begin{tabular}{|l|}
$687.30 \pm 19.88$ \\
\end{tabular} & $77.86+241$ & $154.74 \pm 4.03$ & $49.72+1.35$ & $11.38+4.07$ & $41.54 \pm 3.38$ & $25.95+0.74$ \\
\hline Significant effect & -1 & - & 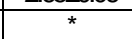 & sent & & & & & & & NS \\
\hline \multicolumn{12}{|l|}{ Sources: } \\
\hline SBM & $4.29 \pm 0.08 c$ & $2.15 \pm 0.03 c$ & $2.14 \pm 0.07 \mathrm{c}$ & $1.01 \pm 0.04 a b$ & $875.57 \pm 2293 a$ & $108.28 \pm 3.54 a$ & $209.14 \pm 5.02 a$ & $66.40 \pm 221 a$ & $67.63+8.82 b$ & $89.16 \pm 9.34 a$ & $27.83+283$ \\
\hline SFM & $5.71 \pm 0.07 a$ & $3.06 \pm 0.02 a$ & $299 \pm 0.04 a$ & $0.91 \pm 0.03 \mathrm{~b}$ & $646.59+26.34 \mathrm{~b}$ & $69.42+214 b$ & $14284 \pm 3.24 b$ & $43.0 \pm 291 \mathrm{c}$ & $4 \pm 5.18 \mathrm{a}$ & $3288+1.31 \mathrm{~b}$ & $26.27 \pm 1.47$ \\
\hline SM & $5.26 \pm 0.09 \mathrm{~b}$ & $277 \pm 0.07 \mathrm{~b}$ & $249 \pm 0.06 \mathrm{~b}$ & $1.10 \pm 0.04 a$ & $671.31+28.25 b$ & $76.17 \pm 213 b$ & $148.50 \pm 3.13 b$ & $50.87 \pm 1.08 b$ & $107.28+5.74 a$ & $34.33+1.48 b$ & $25.0 \pm 0.0$ \\
\hline Overallmean & \begin{tabular}{|l|}
$5.32+0.08$ \\
\end{tabular} & $280 \pm 0.05$ & $265 \pm 0.06$ & $1.0 \pm 0.02$ & \begin{tabular}{|l|}
$687.30 \pm 19.88$ \\
\end{tabular} & $77.86+241$ & $154.74 \pm 4.03$ & $49.72+1.35$ & $101.38+4.07$ & $41.54 \pm 3.38$ & \begin{tabular}{|l|}
$25.95 \pm 0.74$ \\
\end{tabular} \\
\hline Significanteffect & & & & 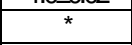 & Cor. & - & & 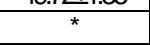 & & 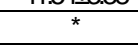 & NS \\
\hline \multicolumn{12}{|l|}{ Levels(\%): } \\
\hline 100 & $4.29+0.08 c$ & $2.15+0.03 c$ & $2.14 \pm 0.07 \mathrm{~b}$ & $1.01 \pm 0.04$ & $857.41+2293 a$ & $10828+3.54 a$ & $209.14 \pm 5.02 \mathrm{a}$ & $66.40+221 a$ & $67.63+8.82 b$ & $89.16 \pm 9.34 a$ & $27.83+283$ \\
\hline 25 & $5.42+0.12 \mathrm{ab}$ & $289+0.08 a b$ & $265 \pm 0.10 a$ & $1.06 \pm 0.07$ & $626.41 \pm 40.54 b$ & $74.04 \pm 297 \mathrm{~b}$ & $144.65+3.97 \mathrm{~b}$ & $48.76 \pm 1.58 b$ & $111.32+8.04 a$ & $3325+1.69 \mathrm{~b}$ & $26.41 \pm 1.41$ \\
\hline 50 & $5.36 \pm 0.12 b$ & $282+0.08 b$ & $271 \pm 0.10 \mathrm{a}$ & $0.95 \pm 0.04$ & $706.27 \pm 28.25 \mathrm{~b}$ & $75.67+268 b$ & $148.97+287 b$ & $46.62+1.66 \mathrm{~b}$ & $104.70 \pm 5.02 a$ & $3325+1.690$ & $26.41 \pm 1.41$ \\
\hline 100 & $5.68 \pm 0.09 a$ & $3.05 \pm 0.04 a$ & $286 \pm 0.08 a$ & $0.99+0.04$ & $644.16+27.20 \mathrm{~b}$ & $68.67+241 \mathrm{~b}$ & $143.40 \pm 4.87 \mathrm{~b}$ & $45.43 \pm 1.48 b$ & $105.0 \pm 6.82 a$ & $34.33+1.84 \mathrm{~b}$ & $24.08+0.91$ \\
\hline Overall mean & \begin{tabular}{|l|}
$5.32+0.08$ \\
\end{tabular} & $280 \pm 0.05$ & $265 \pm 0.06$ & $1.0+0.02$ & \begin{tabular}{|l|}
$687.30 \pm 19.88$ \\
\end{tabular} & $77.86+241$ & \begin{tabular}{|l|}
$154.74 \pm 4.03$ \\
\end{tabular} & $49.72+1.35$ & \begin{tabular}{|l|}
$101.38+4.07$ \\
\end{tabular} & $41.54 \pm 3.38$ & \begin{tabular}{|l|}
$25.95 \pm 0.74$ \\
\end{tabular} \\
\hline Significant effect & 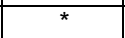 & 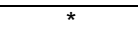 & $=$ & $\mathrm{N}$ & 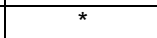 & $=$ & 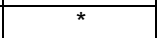 & * & t & * & NS \\
\hline \multicolumn{12}{|l|}{ Sex } \\
\hline Female & $5.30 \pm 0.12$ & $279+0.07 \mathrm{~b}$ & $266 \pm 0.08$ & $0.99+0.04 b$ & $665.75+3237 \mathrm{~b}$ & $75.07 \pm 3.49 \mathrm{~b}$ & $153.97 \pm 6.090$ & $48.85+2220$ & $100.10 \pm 5.55 b$ & $36.76 \pm 3.6 b$ & $27.42+1.3$ \\
\hline Male & $5.33 \pm 0.13$ & $281 \pm 0.08 \mathrm{a}$ & $265 \pm 0.08$ & $1.02+0.03 a$ & $708.85+2292 \mathrm{a}$ & $80.65 \pm 3.31 a$ & $155.50 \pm 5.42 a$ & $50.58+1.57 a$ & $10266+6.09 a$ & $44.33+5.75 a$ & $24.47 \pm 0.52 b$ \\
\hline Overallmean & \begin{tabular}{|l|}
$5.32+0.08$ \\
\end{tabular} & $280 \pm 0.05$ & $265 \pm 0.06$ & $1.0 \pm 0.02$ & $687.30 \pm 19.88$ & $77.86+241$ & $154.74 \pm 4.03$ & $49.72+1.35$ & \begin{tabular}{|c|c|}
$101.38+4.07$ \\
\end{tabular} & $41.54 \pm 3.38$ & $25.95 \pm 0.74$ \\
\hline Significant effect & NS & NS & NS & * & * & * & * & * & * & * & * \\
\hline
\end{tabular}

Means in the same column have the different superscript are significantly different at $(p \leq 0.05)$

*SBM=Soybean meal, SSM=Sesame meal, SFM=Sunflower meal.

1-ALT= Aspartate transaminase

2-AST= Alanine transaminase 
Abdel-Hakim, N. F. et al.

Table (7): The economical efficiency of the experimental diets.

\begin{tabular}{|c|c|c|c|c|c|c|c|}
\hline \multirow[b]{2}{*}{ Items } & \multicolumn{7}{|c|}{ Treatments } \\
\hline & $\begin{array}{c}\text { T1 } \\
100 \% \text { SBM } \\
\text { (control) }\end{array}$ & $\begin{array}{c}\text { T2 } \\
25 \% S S M\end{array}$ & $\begin{array}{c}\text { T3 } \\
50 \% \text { SSM }\end{array}$ & $\begin{array}{c}\text { T4 } \\
100 \% S S M\end{array}$ & $\begin{array}{c}\text { T5 } \\
25 \% \text { SFM }\end{array}$ & \begin{tabular}{c|} 
T6 \\
$50 \%$ SFM
\end{tabular} & $\begin{array}{c}T 7 \\
100 \% \text { SFM }\end{array}$ \\
\hline Initial body weight g/bird. & $18.04 \pm 0.27$ & $17.99 \pm 0.39$ & $17.82 \pm 0.39$ & $17.02 \pm 0.31$ & $16.94 \pm 0.42$ & $17.30 \pm 0.63$ & $16.93 \pm 0.40$ \\
\hline Final body weight g/bird. & $178.16 \pm 7.30 \mathrm{c}$ & $171.04 \pm 2.9 d$ & $192.99 \pm 5.9 a b$ & $203.75 \pm 7.9 a b$ & $193.28 \pm 13.50 b$ & $206.50 \pm 6.6 \mathrm{a}$ & $206.03 \pm 74 a$ \\
\hline Total amount of feed intake/g/bird/period. & $541 \pm 2.57 a$ & $435 \pm 2.60 \mathrm{~b}$ & $525 \pm 2.33 c$ & $5.19 \pm 3.57 d$ & $513 \pm 0.50 d$ & $509 \pm 2.57 \mathrm{c}$ & $506 \pm 2.59 c$ \\
\hline Feed $\operatorname{cost}(\mathrm{PT}) /$ chick $^{1}$ & 90 & 89 & 87 & 85 & 85 & 84 & 84 \\
\hline Price of chick at 1 day of age $(\mathrm{PT})^{2}$. & 50 & 50 & 50 & 50 & 50 & 50 & 50 \\
\hline Cost of husbandry ${ }^{3}$ & 50 & 50 & 50 & 50 & 50 & 50 & 50 \\
\hline Total cost (PT) chick & 190 & 189 & 187 & 185 & 185 & 184 & 184 \\
\hline Sale price of one bird (PT) ${ }^{4}$ & 600 & 600 & 600 & 600 & 600 & 600 & 600 \\
\hline Net revenue $(\mathrm{PT})$ / bird & 410 & 411 & 413 & 415 & 415 & 416 & 416 \\
\hline Relative economic efficiency 5 & 215.79 & 217.46 & 220.86 & 224.32 & 224.32 & 226.09 & 226.09 \\
\hline$\%$ control $^{6}$ & 100 & 100.77 & 102.35 & 103.95 & 103.95 & 104.77 & 104.77 \\
\hline
\end{tabular}

1-Accodring to the price of the different ingredients available in Egypt at 2009

2-Fixed cost

3-Price of 1 husbundry comprise of drugs, light and labor.

4-Price of one bird $=600 \mathrm{PT}$

5 - Net revenue per unit total cost

6-Assuming that the relative economical efficiency of control group equals $100 \%$. 